\title{
Traditional and geometric morphometrics supporting the differentiation of two new Retracrus (Phytoptidae) species associated with heliconias
}

\author{
Denise Navia $^{1}$ - Cecília B. S. Ferreira ${ }^{2}$ - Aleuny C. Reis ${ }^{2} \cdot$ \\ Manoel G. C. Gondim Jr. ${ }^{2}$
}

Received: 2 January 2015/Accepted: 26 May 2015/Published online: 19 June 2015

(C) Springer International Publishing Switzerland 2015

\begin{abstract}
Cryptic diversity has been confirmed for several phytophagous mites in the Eriophyoidea superfamily previously considered as presenting low host specificity. Among generalist eriophyoids is the phytoptid Retracrus johnstoni Keifer, which has been reported in 19 palm species belonging to 11 genera, causing severe damage on some of them. Surprisingly this species was recently reported on another monocot family, Heliconiaceae, infesting Heliconia plants in Costa Rica and Brazil, being the only in the tribe Mackiellini to not be associated with palm trees. This study aimed to investigate the occurrence of cryptic species in $R$. johnstoni and to clarify the taxonomic status of populations associated with heliconias in the Americas. With this purpose traditional and geometric morphometric analyses were conducted as well as a detailed morphological study. Measurable trait data were analysed via univariate and multivariate analyses. Shapes of specimens from different populations were compared via geometric morphometric landmark methods. Morphometric analysis supported occurrence of at least two cryptic species previously identified as $R$. johsntoni and suggested occurrence of cryptic species among populations associated with different palm trees. Taxonomic descriptions of two new taxa associated with heliconias, namely Retracrus costaricensis n. sp. Ferreira and Navia and Retracrus heliconiae n. sp. Ferreira and Navia are presented. Morphometric traits that can be useful in the taxonomic identification are noted and their value is discussed. Results of the traditional morphometry and geometric methods were compared and the advantages of their joint use for Eriophyoidea systematics are discussed.
\end{abstract}

Electronic supplementary material The online version of this article (doi:10.1007/s10493-015-9934-z) contains supplementary material, which is available to authorized users.

Denise Navia

denise.navia@embrapa.br

1 Recursos Genéticos e Biotecnologia, Embrapa, Parque Estaçao Biológica, Final Av. W5 Norte, Asa Norte, 70, Brasília, Distrito Federal 770-900, Brazil

2 Departamento de Agronomia, Universidade Federal Rural de Pernambuco, Bairro dois Irmãos, Recife, Pernambuco CEP 52171-900, Brazil 
Keywords Eriophyoidea $\cdot$ Mackiellini - Tropical America $\cdot$ Cryptic diversity $\cdot$ Host specificity $\cdot$ Integrative taxonomy

\section{Introduction}

Among the plant-feeding mites, the Eriophyoidea are the second most economically important group of pests (Lindquist and Amrine 1996). Several species are known to cause considerable damage in agroecosystems and forestry regions worldwide (Lindquist et al. 1996; Castagnoli et al. 2010; Duso et al. 2010). They are responsible for yield losses via direct damage or virus transmission (Lindquist et al. 1996; Duso et al. 2010) and are subject to quarantine regulations due to their potential as invasive species (Navia et al. 2010).

Misidentification of crop pests may have serious negative implications, i.e., leading to adoption of inappropriate prevention measures or to ineffective control strategies (Armstrong and Ball 2005; Bickford et al. 2007). Elucidation of the cryptic structure of species complexes of pests can mitigate serious negative consequences caused by ignorance of their existence (Bickford et al. 2007; Arthur et al. 2011; Boykin et al. 2012; Rafter et al. 2013; Skoracka et al. 2013). Eriophyoid mite identification is hampered as a result of their small size, structural simplicity (Lindquist and Amrine 1996), and the occurrence of cryptic lineages (Skoracka et al. 2012).

Cryptic diversity has been detected in almost all taxonomic groups (e.g. Hebert et al. 2004; Bickford et al. 2007) and among eriophyoid mites it has been uncovered specially in taxa reported as generalists (Skoracka et al. 2012; Miller et al. 2013). Most of eriophyoid mites have high host specificity (Oldfield 1996; Skoracka et al. 2010); approximately $80 \%$ of the known taxa infest a single plant species and only $5 \%$ of known species are reported infesting plants of different genus or family (Oldfield 1996). Morphometric and molecular studies have showed that two eriophyid taxa previously recognized as generalists, Aceria tosichella Keifer and Abacarus hystrix (Nalepa), both associated with monocots in the Poaceae family, actually comprises a cryptic species-complex, in which some species or lineages have high host specificity (Skoracka and Kuczynski 2006; Carew et al. 2009; Skoracka 2009; Skoracka and Dabert 2010; Skoracka et al. 2012; Miller et al. 2013).

Among generalist eriophyoid mites a Phytoptidae in the Mackiellini tribe, Retracrus johnstoni Keifer, has been reported in 19 palm tree species (Arecaceae) belonging to 11 genera in the Americas-Mexico, Costa Rica and Brazil (Keifer 1965; Ochoa et al. 1994; Santana et al. 1994; Santana and Flechtmann 1998; Gondim Jr. 2000; Furiatti 2001; Abreu 2004; Navia et al. 2007) and also in Africa-Egypt (El-Halawany et al. 2001) (Table 1). In addition to $R$. johnstoni, currently the genus Retracrus presents two more species, both also reported from palm trees-Retracrus elaeis Keifer and Retracrus pupunha Reis and Navia (Keifer 1975; Reis et al. 2012). Retracrus johnstoni and R. elaeis can occur in large populations, causing severe symptoms and damaging their hosts (Genty and Reyes 1977; Genty 1980; Ochoa et al. 1991).

Prior to 2012, mites of the tribe Mackiellini had only been reported to be associated with palms (see Chetverikov et al. 2014). Surprisingly, R. johnstoni was recently reported on another monocot family, Heliconiaceae, infesting and causing damage on Heliconia latispatha Bentham in Costa Rica (Aguilar and Murillo 2012). Populations identified as $R$. johnstoni were also found to be associated with Heliconia pendula Wawra in Bahia State, Brazil (A. R. Oliveira, personal communication). In Costa Rica, symptoms of mite 
Table 1 Palm tree host plants and localities of occurrence of mites in the genus Retracrus

\begin{tabular}{|c|c|c|c|}
\hline Retracrus species & Palm host plant & Country, State & References \\
\hline \multirow[t]{19}{*}{ R. johnstoni Keifer } & $\begin{array}{l}\text { Astrocaryum } \\
\quad \text { aculeatissimum (Schott) }\end{array}$ & Brazil, São Paulo & Gondim Jr. (2000) \\
\hline & Bactris gasipaes Kunth & Brazil, São Paulo & Gondim Jr. (2000) \\
\hline & Bactris setosa Mart & Brazil, São Paulo & Gondim Jr. (2000) \\
\hline & Chamaedorea sp. ${ }^{\mathrm{a}}$ & Mexico (intercepted at USA) ${ }^{b}$ & Keifer (1965) \\
\hline & $\begin{array}{l}\text { Chamaedorea } \\
\text { costaricana } \text { Oersted }\end{array}$ & Costa Rica & Ochoa et al. (1994) \\
\hline & Chamaedorea sp. & Costa Rica & Ochoa et al. (1994) \\
\hline & Cocos nucifera $\mathrm{L}$. & $\begin{array}{l}\text { Brazil-Bahia, Ceará, } \\
\text { Paraíba, Pernambuco, } \\
\text { Rio de Janeiro, Sergipe }\end{array}$ & $\begin{array}{l}\text { Santana et al. (1994), } \\
\text { Santana and } \\
\text { Flechtmann (1998) }\end{array}$ \\
\hline & Elaeis guineensis Jacquin & Brazil, Pernambuco & Gondim Jr. (2000) \\
\hline & Euterpe edulis Mart. & Brazil, São Paulo & Gondim Jr. (2000) \\
\hline & Euterpe oleracea Mart. & Brazil, São Paulo & Navia et al. (2007) \\
\hline & Euterpe precatoria Mart. & Brazil, Amazonas & Navia et al. (2007) \\
\hline & Euterpe sp. & Brazil, Pernambuco & Gondim Jr. (2000) \\
\hline & Geonoma gamiova Barb. Rodr. & Brazil, São Paulo & Gondim Jr. (2000) \\
\hline & Geonoma pohliana Mart. & Brazil, São Paulo & Gondim Jr. (2000) \\
\hline & Geonoma schottiana Mart. & Brazil, São Paulo & Gondim Jr. (2000) \\
\hline & Mauritia flexuosa L. & Brazil, Amazonas & Navia et al. (2007) \\
\hline & Phoenix dactylifera $\mathrm{L}$. & Egypt & El-Halawany et al. (2001) \\
\hline & Scheelea sp. & Brazil, São Paulo & Navia et al. (2007) \\
\hline & $\begin{array}{l}\text { Syagrus romanzoffiana } \\
\text { (Cham.) }\end{array}$ & $\begin{array}{l}\text { Brazil, Rio de } \\
\quad \text { Janeiro, São Paulo }\end{array}$ & $\begin{array}{l}\text { Santana et al. (1994), } \\
\text { Gondim Jr. (2000) }\end{array}$ \\
\hline \multirow[t]{3}{*}{ R. elaeis Keifer } & Elaeis guineensis Jacquin ${ }^{\mathrm{a}}$ & Colombia, Bucaramanga ${ }^{b}$ & Keifer (1975) \\
\hline & Bactris gasipaes Kunth & Costa Rica & Navia et al. (2007) \\
\hline & $\begin{array}{l}\text { Chamaedorea costaricana } \\
\text { Oersted }\end{array}$ & Costa Rica & Navia et al. (2007) \\
\hline $\begin{array}{l}\text { R. pupunha } \\
\text { Reis and Navia }\end{array}$ & Bactris gasipaes Kunth & Brazil, Roraima & Reis et al. (2012) \\
\hline
\end{tabular}

a Type host plant

b Type locality

infestation have been very severe, consisting of generalised chlorosis, rust-coloured damage, or uniform brown-coloured spots that can extend throughout the entire leaf blade (Aguilar and Murillo 2012). Aesthetic damage caused by Retracrus infestations in heliconias certainly compromises the market value of cut flowers, wherein the flowers are packed together with leaves. In Brazil, Retracrus populations are low, and up to now no damage has been observed (A. R. Oliveira, personal communication).

It is possible that populations currently identified as $R$. johnstoni associated with plants of the genus Heliconia in Costa Rica and Brazil comprise cryptic species, i.e., different taxa in the johnstoni complex, as observed for other "generalists" eriophyoid mites. Compared with other eriophyoids, the taxonomic identification of Retracrus mites is especially difficult. This is due to the simplified prodorsal shield ornamentation; the absence of longitudinal lines in the female coverflap; the greatly reduced empodium, which hinders ray counting; and the body often covered by wax, hindering taxonomic traits 
(Keifer 1965, 1975). A reduced number of diagnostic traits are available for distinguishing species (see Keifer 1965, 1975).

"Traditional morphometrics" which consist of univariate and multivariate statistical analyses of sets of quantitative variates, are extremely useful for describing patterns of shape variation within and among groups (Marcus 1990). These morphometric methods have been successfully used in acarology for identifying new species, uncovering cryptic species, differentiating geographic populations, and revealing synonymy of taxa (Baker and Schwarz 1997; Skoracka et al. 2002; Klimov et al. 2006; Navia et al. 2009; Pfingstl et al. 2010; Vidović et al. 2010; Stekol'nikov and Klimov 2010; Wang et al. 2011). As linear distance measurements are usually highly correlated with size (Bookstein et al. 1985), it is interesting to associate analyses of quantitative variates with size-free shape variates using methods that allow for capturing the geometry of the morphological structures and preserving this information throughout the analyses (Adams et al. 2004). The idea of standardising the shape of structures, comparing seta positions using "deformation grids", and quantifying the variation of these positions is old in the context of acarology (see Rowell et al. 1978) and it preceded the development of modern geometric morphometric techniques. Most studies employing these modern tools have been conducted on ticks (Pretorius and Clarke 2000; Clarke and Pretorius 2005), water mites (Becerra and Valdecasas 2004), oribatida (Baran et al. 2011), and scutacarid (JagersbacherBaumann 2014). For the tiny eriophyoid mites, geometric morphometric methods have been poorly explored (Navia et al. 2006; Vidović et al. 2014), although initial results indicate the extreme promise of these techniques (Navia et al. 2006).

This study aimed to investigate the hypothesis of cryptic species occurrence in the genus Retracrus and to clarify the taxonomic status of populations associated with two heliconia species in the Americas by evaluating morphological differences across populations. For this purpose traditional and geometric morphometric analysis as well as a detailed morphological study were conducted. Measurable trait data (linear measurements or counts) were analysed via univariate and multivariate analyses. The shapes of specimens from different populations were compared via geometric morphometric landmark methods. The results of the traditional morphometry and geometric methods were compared. Taxonomic descriptions of the taxa identified as new to science are presented and the most remarkable morphometric differences are presented.

\section{Materials and methods}

\section{Material examined}

Specimens of seven populations preliminarily identified as $R$. johnstoni were studied. Two populations were collected from Heliconia (Heliconiaceae) plants, and five populations were collected from palms (Arecaceae) (Table 2). Samples of heliconia populations were sent by collaborators; Brazilian population was collected by Dr. Anibal Ramadan Oliveira, Universidade Estadual de Santa Cruz, Ilhéus, Bahia, Brazil; Costa Rican population was collected by Dr. Hugo Aguilar, Universidad de Costa Rica, São José, Costa Rica. Number of specimes collected from each population varied from 30 to 60 . Whenever possible, the same individuals were used to obtain both traditional and geometric morphometric data.

Mites were collected through direct examination using a stereomicroscope and preserved in $70 \%$ ethyl alcohol. Retracrus mites are wax producers, and their bodies can be 
Table 2 Studied populations of Retracrus mites, host plants and collection localities

\begin{tabular}{|c|c|c|c|c|}
\hline Host family & Host species & Country & State, locality & Coordinates \\
\hline \multirow[t]{5}{*}{ Arecaceae } & \multirow[t]{4}{*}{ Cocos nucifera $\mathrm{L}$. } & \multirow[t]{4}{*}{ Brazil } & Alagoas, Maragogi & $\begin{array}{l}8^{\circ} 55^{\prime} 23.45^{\prime \prime} \mathrm{S} \\
35^{\circ} 9^{\prime} 32.25^{\prime \prime} \mathrm{W}\end{array}$ \\
\hline & & & Paraíba, Pitimbu & $\begin{array}{l}7^{\circ} 32^{\prime} 9.19^{\prime \prime} \mathrm{S} \\
34^{\circ} 50^{\prime} 0.20^{\prime \prime} \mathrm{W}\end{array}$ \\
\hline & & & $\begin{array}{l}\text { Rio Grande } \\
\text { do Norte, Búzios }\end{array}$ & $\begin{array}{l}6^{\circ} 6^{\prime} 50.08^{\prime \prime} \mathrm{S} \\
35^{\circ} 9^{\prime} 32.00^{\prime \prime} \mathrm{W}\end{array}$ \\
\hline & & & $\begin{array}{l}\text { Pernambuco, } \\
\text { Itamaracá }\end{array}$ & $\begin{array}{l}7^{\circ} 46^{\prime} 11.33^{\prime \prime} \mathrm{S} \\
34^{\circ} 51^{\prime} 5.51^{\prime \prime} \mathrm{W}\end{array}$ \\
\hline & $\begin{array}{l}\text { Syagrus romanzoffiana } \\
\text { (Cham.) }\end{array}$ & Brazil & São Paulo, Piracicaba & $\begin{array}{l}22^{\circ} 42^{\prime} 31.57^{\prime \prime} \mathrm{S} \\
47^{\circ} 37^{\prime} 54.62^{\prime \prime} \mathrm{W}\end{array}$ \\
\hline \multirow[t]{2}{*}{ Heliconiaceae } & $\begin{array}{l}\text { Heliconia pendula } \\
\text { Wawra }\end{array}$ & Brazil & Bahia, Ilhéus & $\begin{array}{l}14^{\circ} 47^{\prime} 45.66^{\prime \prime} \mathrm{S} \\
39^{\circ} 10^{\prime} 01^{\prime \prime} \mathrm{W}\end{array}$ \\
\hline & Heliconia latispatha Bentham & Costa Rica & San José, San José & $\begin{array}{l}9^{\circ} 55^{\prime} 37.66^{\prime \prime} \mathrm{N} \\
84^{\circ} 4^{\prime} 55.24^{\prime \prime} \mathrm{W}\end{array}$ \\
\hline
\end{tabular}

completely covered by dense wax layers, hindering visualisation of taxonomic structures when examined under a microscope. To remove the wax, the mites were maintained for 1 min in Nesbitt's fluid before mounting on slides in modified Berlese medium (Amrine and Manson 1996).

\section{Traditional univariate and multivariate morphometrics}

The morphological parameters obtained were subjected to multivariate analysis of variance (MANOVA) with populations as the independent variate and, if significant, to univariate analysis of variance (ANOVA; GLM procedure); means were compared using StudentNewman-Keuls test. Two multivariate analyses were applied to the data set: canonical variate analysis (CVA) (PROC CANDISC), and discriminant function analysis (PROC DISCRIM). Each population (same host plant and locality) was a priori defined as a group in the discriminant function analysis. All of the analyses were performed using the SAS statistical program (SAS Institute 2002).

Twenty females in dorsoventral position were selected from each population and studied. A total of 39 traits were evaluated for the linear morphometric analyses (Table 3). The characters evaluated were those commonly used and considered important in Eriophyoidea systematics (Amrine and Stasny 1994), excluding some that were difficult to visualise or that could not be measured reliably because (1) were no clearly visualized or were bent (e.g., number of microtubercles of the ventral rings; length of very long setae); (2) were considered to be less important for morphometry, since they are commonly invariable among species; or (3) were difficult to standardise their measurement (e.g., length of the leg segments). The terminology follows Amrine and Stasny (1994). Measurements were conducted according to de Lillo et al. (2010) with the following exceptions: (1) body length was measured from the tip of the frontal lobe to the rear end of the anal lobe, not considering pedipalps; (2) the scapular seta (sc) tubercle distance (between internal tubercle margins) was used instead of base setae distance; (3) empodium length was measured including its basal portion inserted in the tarsus. The count of ventral opisthosomal annuli starts from the first full annulus behind the genitalia. Dorsal opisthosomal annuli were counted from the first full annulus behind the middle of the 


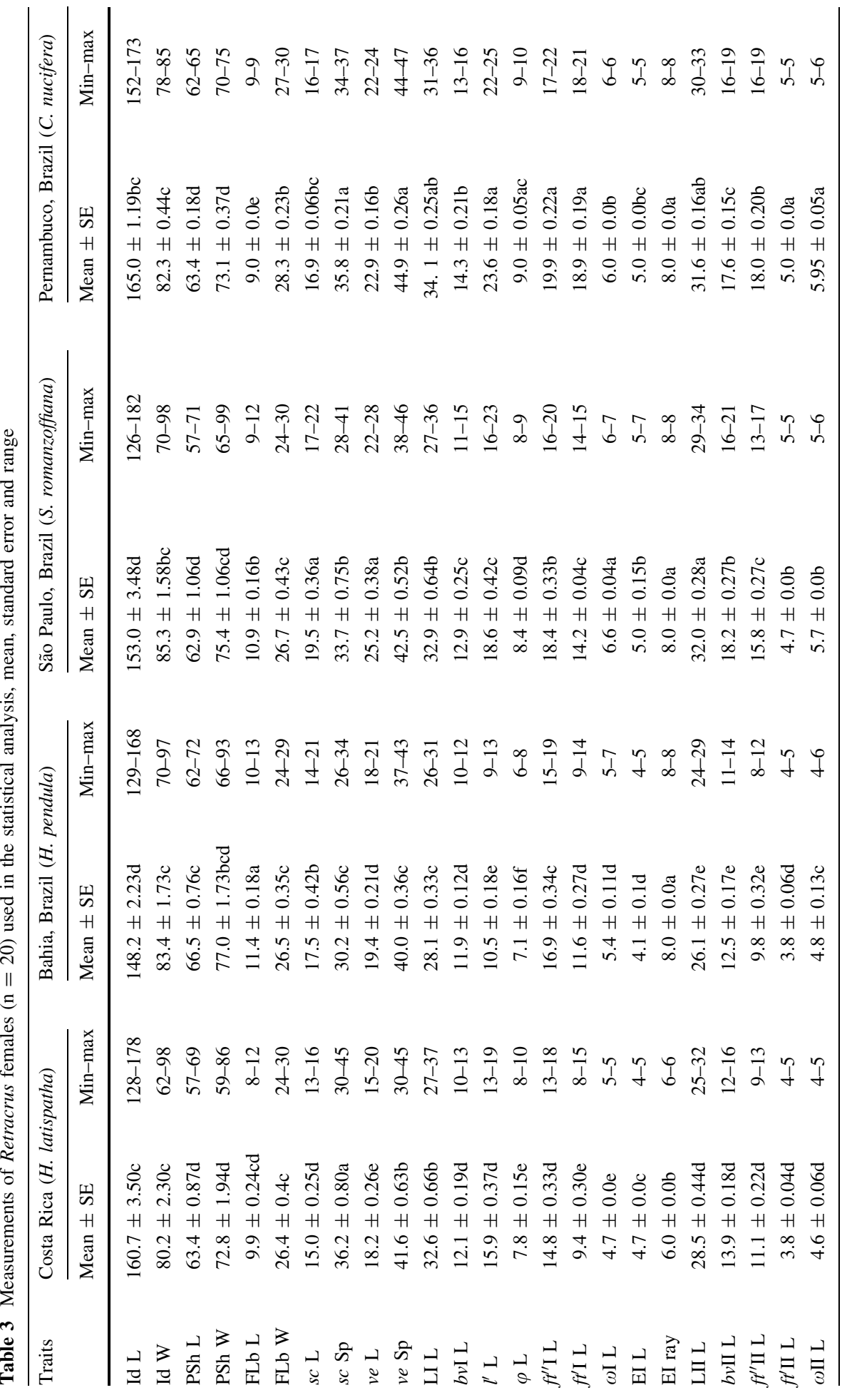




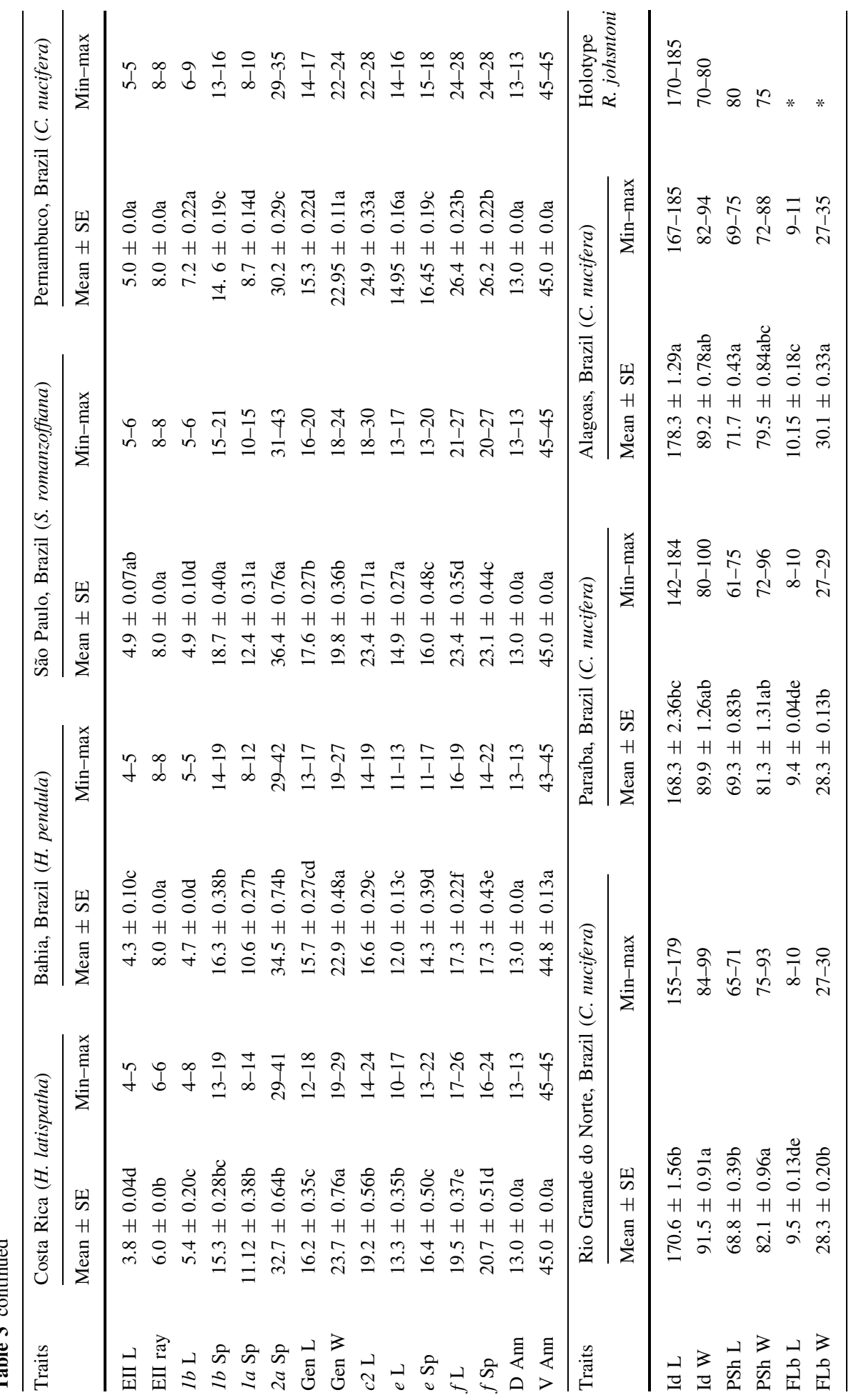




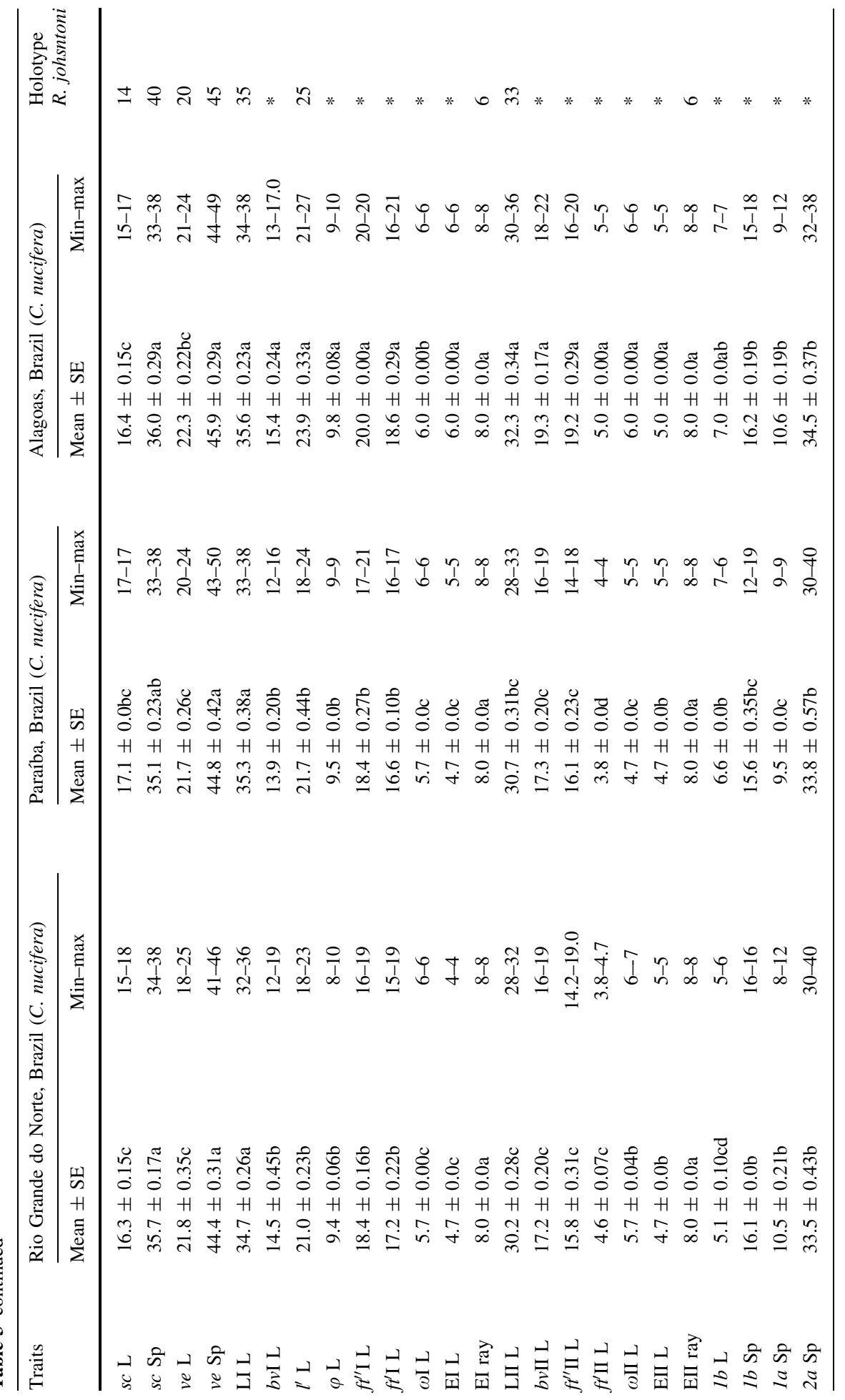




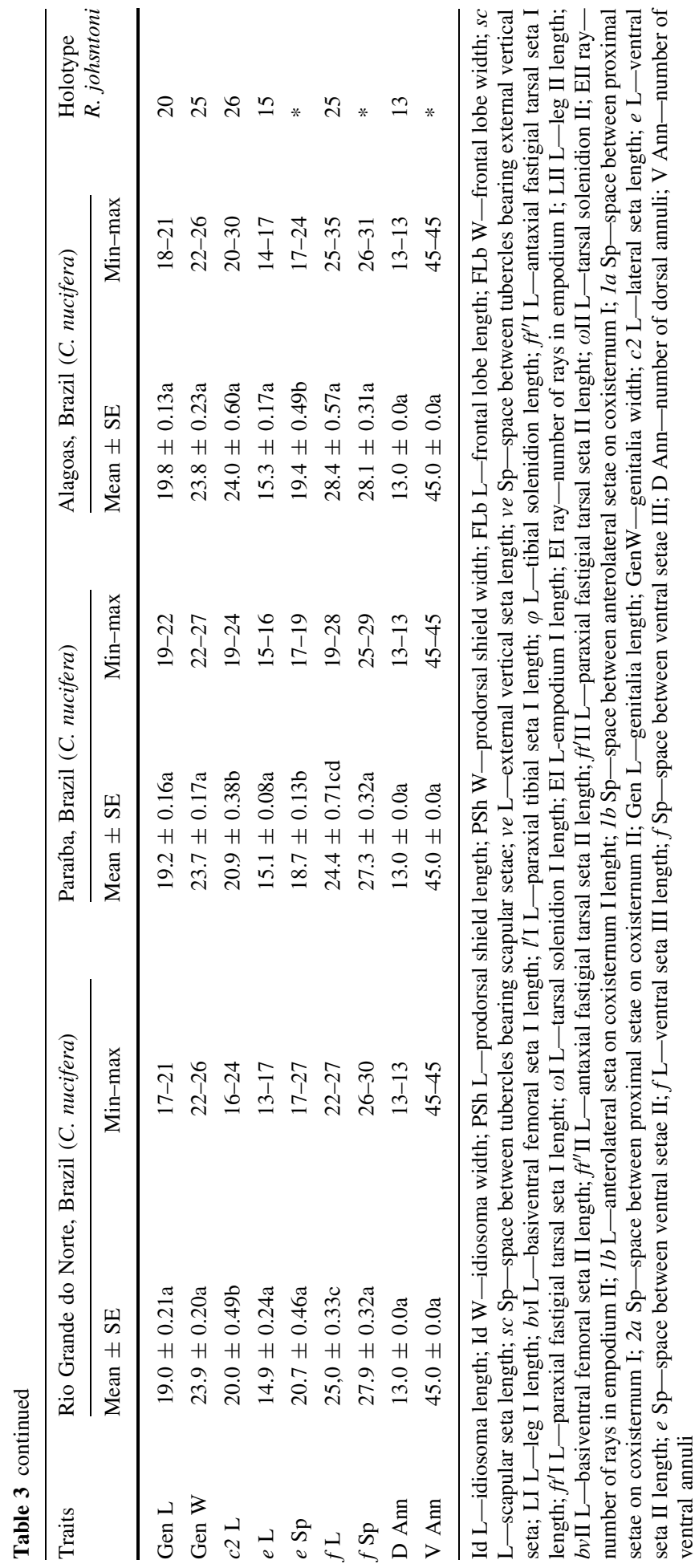


prodorsal shield rear margin. As for sc setae distance, the tubercle distance between the external vertical setae (ve) was considered (not between setae insertions). When a clear difference in lengths was observed between the right and left homologue of the same structure in the same specimen, the longer was considered. When homologous ventral setae were inserted in different annuli, they were considered to be inserted on the anterior annulus. For canonical variate analysis, the numbers of rays of empodia I and II were not considered, as the data did not fit this analysis when these traits were included. All of the measurements and counts were performed under $100 \times$ magnification with an optical phase-contrast microscope (model BX41, Olympus).

Examination of the $R$. johnstoni type material was not possible. In consulting with the curator of the US. National Mite Collection in the United States, no information was obtained on the material's availability. Dr. James W. Amrine Jr. (West Virginia University), a systematics specialist in eriophyoid mites of the US, reported that there was no more type material preserved in slides that were in good enough condition to be studied but that dried material (dry leaves of the host type infested by $R$. johnstoni) had been provided for study to Dr. Philipp Chetverikov, Saint Petersburg State University, Russia. Dr. Chetverikov reported that some specimens have been successfully mounted from the dried material but that they were very damaged. Only a few structural traits could be observed (such as the number of rays of empodium), but it would not be possible to take measurements from the specimens for morphometric studies. Information on the original description of $R$. johnstoni (Keifer 1965) is shown for comparison with the material under study (Table 3).

\section{Landmark-based morphometric methods}

Three body regions were separately analysed through landmark morphometric methodsventral, coxigenital, and prodorsal shield. Fourteen landmarks in the ventral region, 13 in the coxigenital region, and 7 in the prodorsal shield were defined following Bookstein (1991) and its descriptions are presented in Fig. 1.

Females in dorsoventral position, well clarified, and with unbroken body were selected for these analysis. Images $(2048 \times 1536$ pixels resolution $)$ of body regions of the selected females were obtained using a video system consisting of a phase-contrast optical microscope (Eclipse 80i, Nikon) connected to a digital camera (12.7 megapixels, DS-Ri1, Nikon), both connected to a camera control unit (DS Controller, Nikon). Images of the ventral region were obtained using a $40 \times$ magnification objective, while those of the coxigenital and prodorsal shield regions were obtained with a $100 \times$ magnification objective. It was not possible to obtain the same number of good-quality images for each population and body region because some specimens/body regions were partially damaged or insufficiently clarified (very common for the coxigenital region). The number of images obtained for each population and body region are listed in Table 4.

Landmarks were recorded, and their positions were transformed into Cartesian coordinates (x and y) using the Tpsdig software (Rohlf 2010). The raw landmark coordinates were aligned by generalised procrustes analysis (GPA) to remove the variation due to the isometric effects of size, position, and orientation (Rohlf 1999). Tpssmall software was used to determine whether the shape variation of the studied body regions was sufficiently small for the application of the deformation analysis to be possible. This program helps to assess the accuracy of the approximation of shape space by the tangent space (Rohlf 1997).

Shape differences among the analysed populations were further explored using a PCA of the covariance matrix of the Procrustes coordinates averaged by population. In addition, 

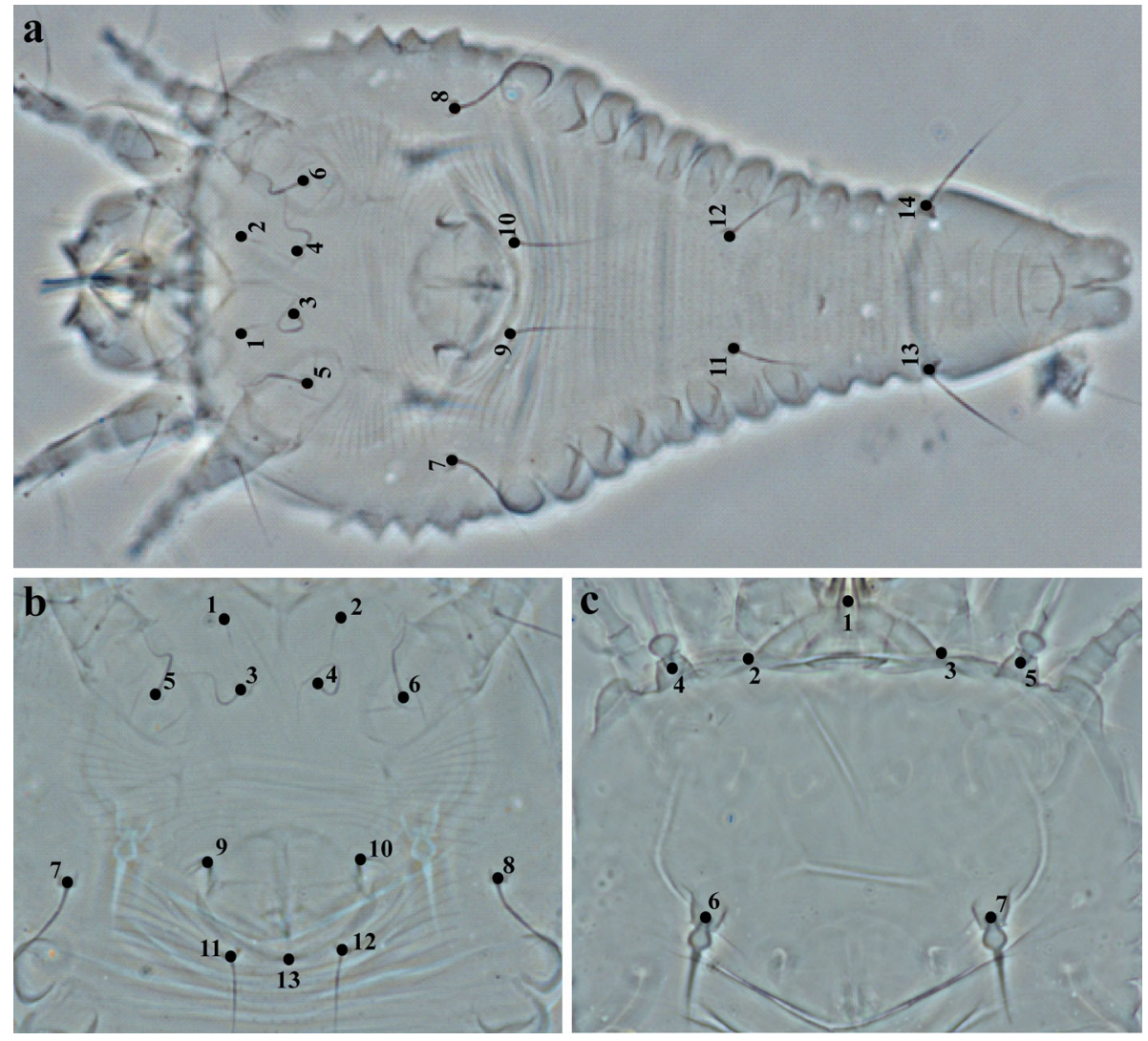

Fig. 1 Landmarks digitised on the ventral, coxigenital and prodorsal shield regions of Retracrus mites bodies. a Ventral region: 1 base of left coxal seta I ( $1 b) ; 2$ base of right coxal seta I ( $1 b)$; 3 base of left coxal seta II (1a); 4 base of right coxal seta II (1a); 5 base of left coxal seta III $(2 a) ; 6$ base of right coxal seta III (2a); 7 base of left lateral seta $(c 2) ; 8$ base of right lateral seta $(c 2) ; 9$ base of left genital seta $(3 a) ; 10$ base of right left genital seta $(3 a) ; 11$ base of left ventral seta II $(e) ; 12$ base of right ventral seta II $(e) ; 13$ base of left ventral seta III $(f) ; 14$ base of right ventral seta III $(f)$. b Coxigenital region: 1 base of left of left coxal seta I (1b); 2 base of right coxal seta I (1b); 3 base of left coxal seta II (1a); 4 base of right coxal seta II (1a); 5 base of left coxal seta III (2a); 6 base of coxal seta III (2a); 7 base of left lateral seta (c2); 8 base of right lateral seta $(c 2)$; 9 left anterolateral margim of epigynium; 10 right anterolateral margim of epigynium; 11 base of left genital seta $(3 a) ; 12$ base of right genital seta $(3 a) ; 13$. posterocentral tip of epigynium. c Prodorsal region: 1 anterior central tip of frontal lobe; 2 left base of frontal lobe; 3 right base of frontal lobe; 4 base of left external vertical seta (ve); 5 base of right external vertical seta (ve); 6 base of left scapular seta $(s c) ; 7$ base of right scapular seta $(s c)$

CVA was performed to reveal the variation among two or more groups of specimens relative to the average variation found within the groups. The overall significance test for CVA is also the appropriate significance test for a single classification multivariate analysis of variance (MANOVA). Distance matrixes were constructed by the generalised distance obtained through CVA. PCA and CVA were performed using MorphoJ software (Klingenberg 2011). Configurations of the anatomical landmarks were superimposed by the least-squares method, which transforms a landmark configuration by superimposing it on a reference configuration (consensus) and then translating, scaling and rotating one of them 
Table 4 Number of digital images obtained for each body region and Retracrus population

\begin{tabular}{llll}
\hline Host, locality, country & \multicolumn{2}{l}{ Body region } & \\
\cline { 2 - 4 } & Ventral & Coxigenital & Prodorsal shield \\
\hline Heliconia latispatha, San José, Costa Rica & 9 & 7 & 10 \\
H. pendula, Ilhéus-BA, Brazil & 10 & 10 & 11 \\
Syagrus romanzoffiana, Piracicaba-SP, Brazil & 12 & 11 & 20 \\
Cocos nucifera, Itamaracá-PE, Brazil & 20 & 20 & 20 \\
C. nucifera, Búzios-RN, Brazil & 11 & 12 & 16 \\
C. nucifera, Pitimbu-PB, Brazil & 20 & 20 & 20 \\
C. nucifera, Maragogi-AL, Brazil & 20 & 19 & 20 \\
\hline
\end{tabular}

so that the sum of squares of the distances between the corresponding points of the configurations would as low as possible. The consensus configuration was separately obtained for each body region and population with the purpose of analysing differences between population averages using Relative Warp Analysis (RWA) in the Tpsrelw software (Rohlf 1998).

\section{Taxonomic descriptions}

Two new taxa identified as new to science were described based on morphometric analysis and detailed observations of their external morphology. Measurements were taken from females, males, and immature forms (larvae and nymphs). Drawings were made in a lucid chamber under a phase-contrast microscope (model BX41, Olympus) at $100 \times$ magnification. The drawings were scanned, digitised and elaborated using the Adobe Illustrator CS3 program. Measurements or counts were taken as aforementioned (univariate and multivariate morphometrics). All of the measurements are in micrometers $(\mu \mathrm{m})$ unless otherwise noted. The measurements of the holotype precede the paratype ranges. Some measurements were not obtained due to the mite position in the slides. It was not possible to measure the cheliceral stylets due to overlap with other structures of the gnathosoma, such as palps and oral stylets. The terminology used was according to that proposed by Amrine and Stasny (1994). Morphometric traits with significant differences (SNK test) and without measurements overlapping with the other species in the group were considered as useful for taxonomic identification and are noted in the description remarks.

\section{Results}

\section{Traditional univariate and multivariate morphometrics}

The minimum and maximum values observed, with means and standard error of each of the 39 traits used in the morphometric analyses for the seven Retracrus populations from heliconias and palms, are exhibited in Table 3. The measurements/counts of the traits of the $R$. johnstoni holotype presented by Keifer (1965) in the original description are also presented.

The MANOVA showed significant differences among populations (GLnum/den $=222$ / 584.16, Wilks' Lambda $=0.00000033$ and $\mathrm{F}=30 ; P<0.0001)$. The univariate analyses 
(Student-Newman-Keuls test) revealed significant differences among 37 of the 39 traits studied in the Retracrus populations; the only traits that did not significantly differ were number of dorsal and ventral rings. For several traits there was no variation (minimummaximum) overlapping among the populations (Table 3). Fifteen traits were significant different between the heliconian populations and palm populations; 27 traits significantly differed among the two heliconia populations. In the comparison of the heliconia populations with those from the palms, the following traits exhibited significant differences with no or little overlap in variation ranges: setae and legs appendices lengths; length and distance between ve; and length and distances between opisthosomal ventral setae II $(e)$ and III $(f)$. In general, for these traits, the heliconia populations from both Brazil and Costa Rica exhibited lower values. Among the Brazilian and Costa Rican heliconia populations, the following traits exhibited significant differences with no or little overlap in variation ranges: length of paraxial tibial seta $\left(l^{\prime}\right)$ and tibial solenidion $(\varphi)$, and number of rays of the empodia of legs I and II. The Retracrus population from $H$. pendula from Brazil has a shorter body than all of the other populations studied and the R. johnstoni type material. The $H$. latispatha population from Costa Rica has six rays on the empodium, whereas eight rays were counted for all other populations.

The two first canonical variates (CV1 and CV2) explained $80.66 \%$ of the total variation present in the covariance matrix among the traits of the populations analysed: CV1 explained $62.97 \%$, and CV2 explained $17.69 \%$. The projection graph of the individuals in space of the first two canonical variates (Fig. 2a) showed there was no overlap among the representatives of each of the heliconia populations or between these and the palm populations ( $S$. romanzoffiana and $C$. nucifera); these populations were completely separate, revealing morphometric differentiation among them. Coconut tree populations from Pernambuco, Rio Grande do Norte, Alagoas and Paraíba were clustered, being overlapped or continuous, revealing morphometric proximity among them. The heliconia populations were differentiated from all palm tree populations along the CV1 axis. The $S$. romanzoffiana population was differentiated from all $C$. nucifera populations and from the Costa Rica heliconia population and along the CV2 axis. The two heliconia populations (Costa Rica and Brazil) were differentiated along both axes, but especially along the CV2 axis.

According to the CVA, the traits (eigenvectors) that contributed the most (higher eigenvalues loadings) to distinguishing the heliconia populations from all of the palm tree populations (Canonical variate 1) were the following, in decreasing order: lengths of the paraxial fastigial tarsal seta $\left(f t^{\prime}\right)$ of legs I and II, of the $l^{\prime}$ seta on leg I, of the basiventral femoral seta $(b v)$ on leg II, and of the tarsal solenidion $(\omega)$ on leg I; length and distance between the ventral setae III $(f)$; and length of the antaxial fastigial tarsal seta $\left(f t^{\prime \prime}\right)$ on leg II. Similarly, the traits that contributed most for distinguishing the two heliconia populations, as well as for distinguishing the $S$. romanzoffiana population from the coconut tree populations (Canonical variate 2) were as follows: lengths of the $\omega$ solenidion on leg I, of the $f^{\prime}$ seta on leg I, and of the ve seta; distance between $s c$ seta; and length of the idiosoma.

In comparing the measurements of the morphometric traits of the Retracrus populations obtained in this study and those of the type material presented by Keifer (1965) (Table 3), the $C$. nucifera populations are closest to the original description. Although it was not possible to conduct statistical analyses, it can be stated that marked differences are observed among the measurements of the Heliconia and S. romanzoffiana populations compared with the type material. The main differences were observed in the length of the idiosoma and the prodorsal shield; in the length and distance of the sc setae; in the length of the legs and legs setae; in the length and width of the genitalia; and in the length of the opisthosomal setae. 
Fig. 2 Canonical variate analysis (CVA) of females morphometric traits of Retracrus populations from palm trees and heliconias from the Americas. a CVA of traditional morphometric traits (measurements and counts), b CVA of shape coordinates of the ventral region, $\mathbf{c}$ CVA of shape coordinates of the coxigenital region and $\mathbf{d}$ CVA of shape coordinates of the prodorsal shield. Individuals plotted against their values for the first two canonical variates. Red circle: Cocos nucifera, Alagoas, Brazil; Orange circle: C. nucifera, Paraíba, Brazil; Violet circle: $C$. nucifera, Pernambuco, Brazil; Pink circle: C. nucifera, Rio Grande do Norte, Brazil; Light blue circle: Heliconia latispatha, San José, Costa Rica; Dark blue circle: $H$. pendula, Bahia, Brazil; Green circle: Syagrus romanzoffiana, São Paulo, Brazil. (Color figure online)
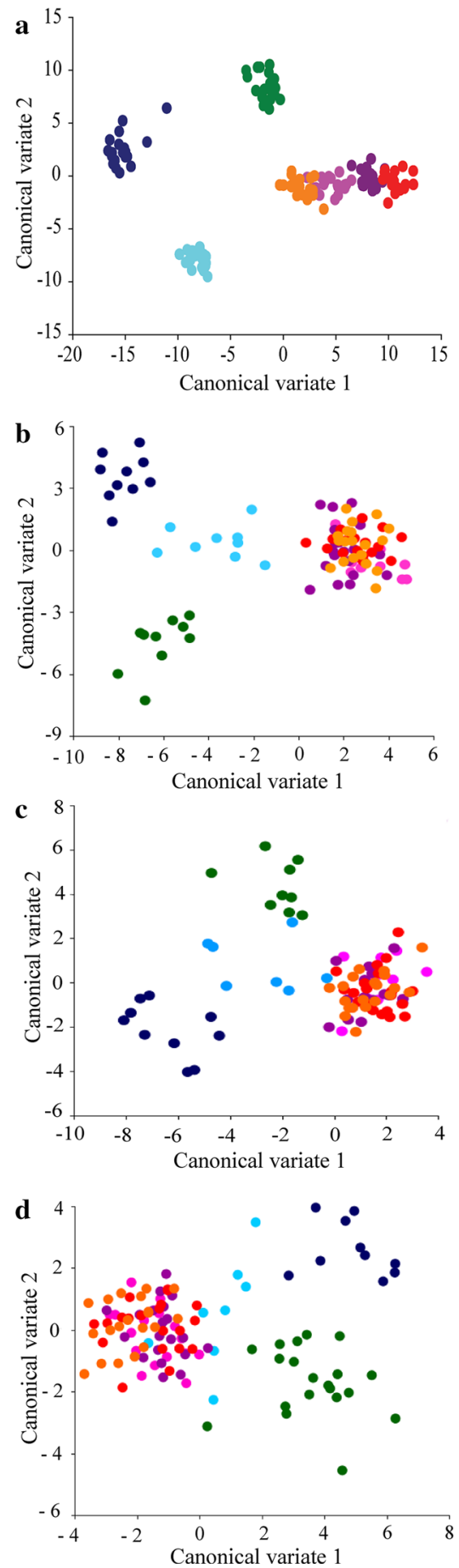
Discriminant function analysis, through which the classification of the specimens was predicted, showed that all of the individuals were correctly classified in their populations of origin based on morphological similarities, except for one specimen from $H$. pendula from Bahia, Brazil, which was classified as belonging to the population from $S$. romanzoffiana from São Paulo, Brazil; and two specimens from $C$. nucifera from Rio Grande do Norte, Brazil, which were classified as belonging to the $C$. nucifera population from Paraíba. The correct prediction of most specimens in its respective populations corroborate CVA results, showing morphometric differentiation among studied populations and that coconut populations are the closest morphometrically.

\section{Landmark-based morphometric methods}

Analyses were conducted to obtain information on the morphological variations among Retracrus populations. The variation in shape found in each dataset was small enough to allow the statistical analyses to be performed in the tangent space (which is linear) approximate to Kendall's shape space (which is nonlinear).

The PCA performed on shape coordinates of 14 landmarks in the ventral region of 100 specimens from the seven studied populations resulted in 24 principal components, with the first two components explaining $67.25 \%$ of the total variation (PC1 $47.52 \%$, PC2 $19.73 \%)$. CVA performed on the same dataset showed that the first two canonical variates explained $90.26 \%$ of the total variation (CV1 $73.46 \%$, CV2 $16.8 \%$ ). In the RWA performed on the population consensus configuration, the two first relative warps (RW1 and RW2) explained $92.99 \%$ of the total variation (RW1 $70.58 \%$, RW2 explained $22.41 \%$ ).

The PCA performed on shape coordinates of 13 landmarks in the coxigenital region of 100 specimens from the seven studied populations resulted in 22 principal components, with the first two components explaining $75.86 \%$ of the total variation (PC1 $62.78 \%$, PC2 $13.08 \%)$. CVA performed on the same dataset showed that the first two canonical variates explained $82.23 \%$ of the total variation (CV1 $60.83 \%$, CV2 $21.39 \%$ ). In the RWA performed on the population consensus configuration, the two first relative warps explained $95.10 \%$ of the total variation (RW1 $82.66 \%$, RW2 $12.44 \%$ ).

The PCA performed on shape coordinates of seven landmarks in the prodorsal shield region of 117 specimens from the seven studied populations resulted in 10 principal components, with the first two components explaining $52.3 \%$ of the total variation (PC1 $30.91 \%$, PC2 $21.47 \%$ ). CVA performed on the same dataset showed that the first two canonical variates explained $91.92 \%$ of the total variation (CV1 $77.86 \%$, CV2 $14.06 \%$ ). In the RWA performed on the population consensus configuration, the two first relative warps explained $88.89 \%$ of the total variation (RW1 $48.77 \%$, RW2 $40.12 \%$ ).

The PCA and CVA scatterplots of the three body regions of Retracrus mites-ventral (Figs. 2b, 3), coxigenital (Figs. 2c, 4) and prodorsal shield (Figs. 2d, 5) from seven populations from heliconias and palm trees showed similar patterns, though in the CVA plots, specimens from each population were more clustered, and groups could be better segregated. The analysis revealed a clear distinction of populations related to the host plant. Specimens from all coconut tree populations were widely overlapped, whereas those from the palm tree $S$. romanzoffiana and from the two heliconias- $H$. latispatha and $H$. pendula -were completely separated or presented reduced overlap with the coconut specimens and also with one another. The population from H. latispatha was the most similar to the coconut tree populations, and for all body regions these specimens were plotted in an intermediate position between the coconut tree, $H$. pendula and $S$. romanzoffiana populations. Coxigenital and prodorsal shield CVA scatterplots (Fig. 2c, d) revealed the total 


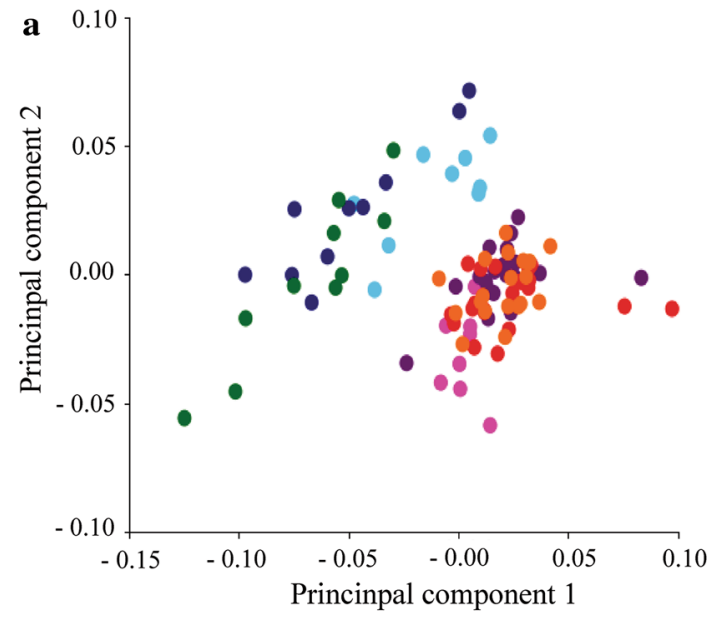

b
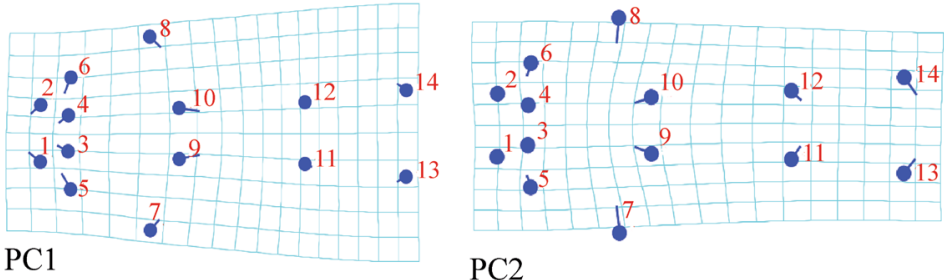

PC2

c

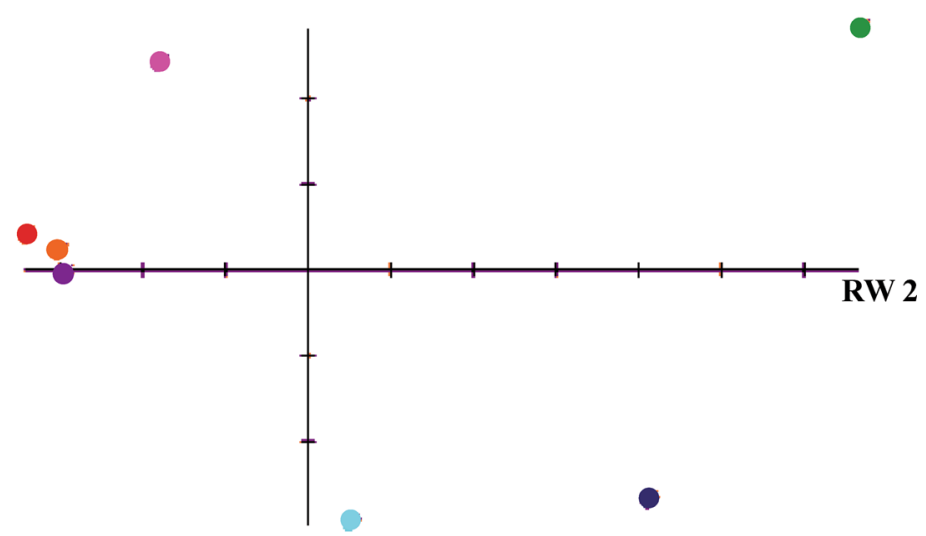

\section{RW 1}

Fig. 3 Morphometric geometric analysis for the ventral region of Retracrus females from population associated with palm trees and heliconias in the Americas. a Principal component analysis (PCA). Individuals plotted against their values for the first two principal components. b Variations in shapes are presented in the form of transformation grids along the principal components 1 and 2 axis. $\mathbf{c}$ Relative warps (RW) for values $\alpha=0$. Population consensus plotted against their values for the first two relative warps. Red circle: Cocos nucifera, Alagoas, Brazil; Orange circle: C. nucifera, Paraíba, Brazil; Violet circle: C. nucifera, Pernambuco, Brazil; Pink circle: C. nucifera, Rio Grande do Norte, Brazil; Light blue circle: Heliconia latispatha, San José, Costa Rica; Dark blue circle: H. pendula, Bahia, Brazil; Green circle: Syagrus romanzoffiana, São Paulo, Brazil. (Color figure online) 
distinction of $H$. pendula and $S$. romanzoffiana populations; however, they also revealed that the H. latispatha population was not completely distinct, showing some proximity especially with the coconut tree and S. romanzoffiana populations. The CVA results showed that among the body regions studied, the ventral region (Fig. 2b) best distinguished specimens/populations from different host plants. CVA scatterplot of the ventral region is the most similar to that of the traditional morphometric analyses (Fig. 2a, b).

The consensus RWA showed that coconut tree populations were plotted along the negative RW1 axis, whereas populations from the other host plants were plotted along the positive axis (Figs. 3c, 4c, 5c). Within the coconut tree populations, this analysis revealed that those from Alagoas, Paraíba and Pernambuco are more similar to each other with respect to the ventral and coxigenital regions (Figs. 3c, 4c), while for the prodorsal shield region, those from Alagoas, Pernambuco and Rio Grande do Norte are the more similar (Fig. 5c). RWA scatterplots showed that the two heliconia populations are more similar with respect to the ventral and coxigenital regions than the prodorsal shield (Figs. 3c, 4c, $5 c)$. The $S$. romanzoffiana population is very distinct from all other coconut tree populations, particularly in the ventral and coxigenital region (Figs. 3c, 4c).

The main ventral shape differences among populations revealed through PCA include genitalia position, which was shifted or not from the coxal area; coxal region compression, reflected by the distances between coxae and the posterior opisthosoma width; lateral seta position, which can be more or less shifted from the genitalia; and posterior opisthosoma constriction at the level of $e$ and $f$ setae, reflected by the distances between setae. PCA ventral deformation grids indicated differences in body shape between populations (see Supplementary material 1); in some populations, the body is relatively shorter and wider, while in others, they are larger and narrow. Ventral deformation grids from the coconut tree populations are quite similar, while for the Retracrus mites from heliconia populations (H. pendula and H. latispatha) and from S. romanzoffiana, some shape differences were quite remarkable. For these populations, the posterior opisthosoma is narrower than the anterior opisthosoma. In the $S$. romanzoffiana population, the body is wider at the level of the genitalia and lateral seta $(c 2)$; another difference is in the distance between proximal setae on coxisternum I ( $1 a$ ). In $H$. pendula population, the genitalia are nearer to the coxae (reflected by the base of the genital setae ( $3 a$ ) being closer to the genitalia). In H. latispatha population, the $1 a$ setae are more distant than in $H$. pendula population.

For the coxigenital region, the main shape differences include the lateral compression of the genital area, reflected by the distance between $c 2$ setae, and the length of the genitalia, reflected by the relative position of the posterocentral tip of the epigynium. Compared with palm populations, in heliconia populations, the genitalia are shorter; this difference was more notable in $H$. pendula population. As visualised in the ventral grids (see Supplementary material 1) but more evident in the coxigenital grids (see Supplementary material 2 ), in populations from heliconias and $S$. romanzoffiana, the body is narrower at the level of the genitalia (reflected by distance between $c 2$ setae) than in coconut tree populations.

For the prodorsal shield region, the main differences include the frontal lobe length, reflected by the distance between the frontal lobe tip and bases; the relative position of ve setae which can be anterior, posterior or on the level of the frontal lobe base; and the width of the frontal lobe (see Supplementary material 3). In coconut tree populations, frontal lobe lengths are quite similar, and ve seta bases are at the level of the frontal lobe base (insertion). Distinctly in the H. latispatha and in S. romanzoffiana populations, the ve bases are slightly posterior to the frontal lobe base, whereas they are shifted anteriorly in the populations from $H$. pendula. In $S$. romanzoffiana population the frontal lobe is longer and narrower than in the other populations. 


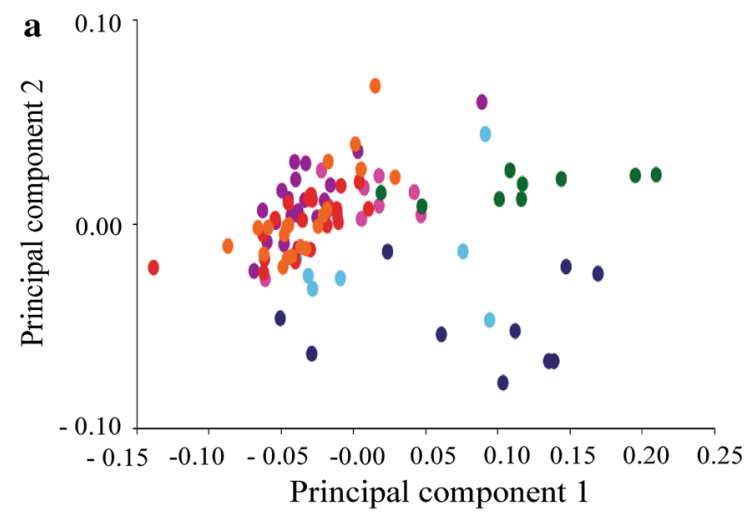

b

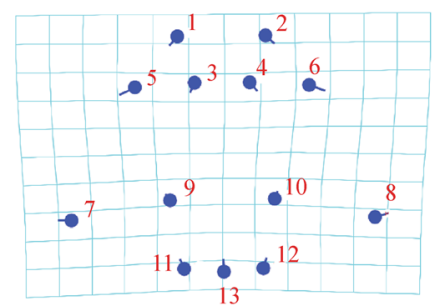

PC1

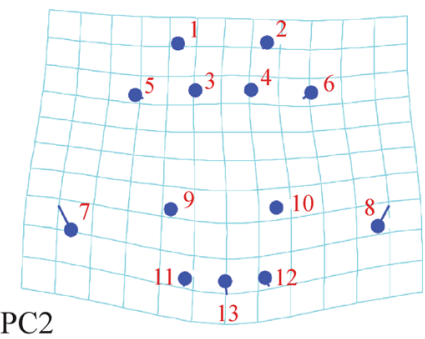

PC2

c

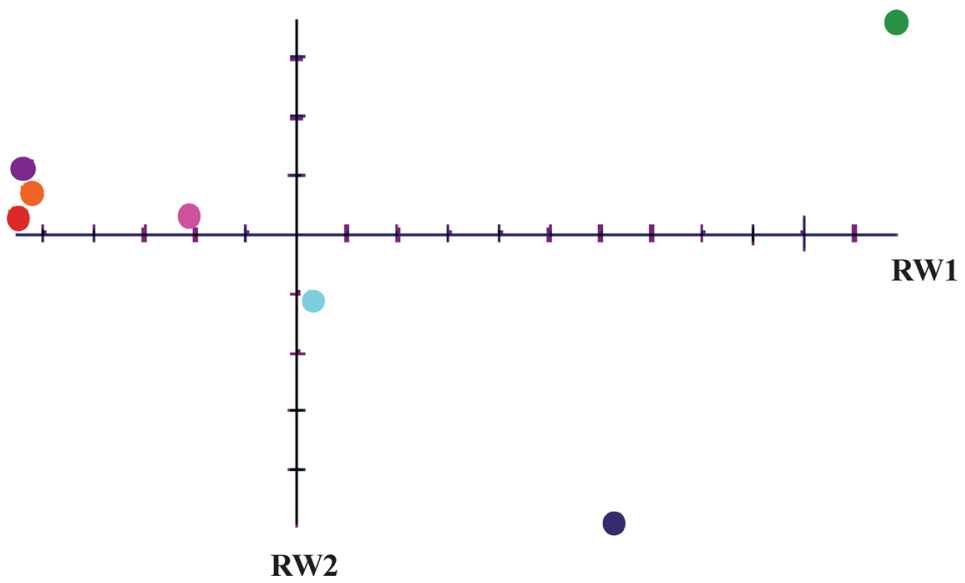

Fig. 4 Morphometric geometric analysis for the coxigenital region of Retracrus females from population associated with palm trees and heliconias in the Americas. a Principal component analysis (PCA). Individuals plotted against their values for the first two principal components. $\mathbf{b}$ Variations in shape $s$ are presented in the form of transformation grids along the principal components 1 and 2 axis. c Relative warps (RW) for values $\alpha=0$. Population consensus plotted against their values for the first two Relative Warps. Red circle: Cocos nucifera, Alagoas, Brazil; Orange circle: C. nucifera, Paraíba, Brazil; Violet circle: $C$. nucifera, Pernambuco, Brazil; Pink circle: C. nucifera, Rio Grande do Norte, Brazil; Light blue circle: Heliconia latispatha, San José, Costa Rica; Dark blue circle: H. pendula, Bahia, Brazil; Green circle: Syagrus romanzoffiana, São Paulo, Brazil. (Color figure online) 


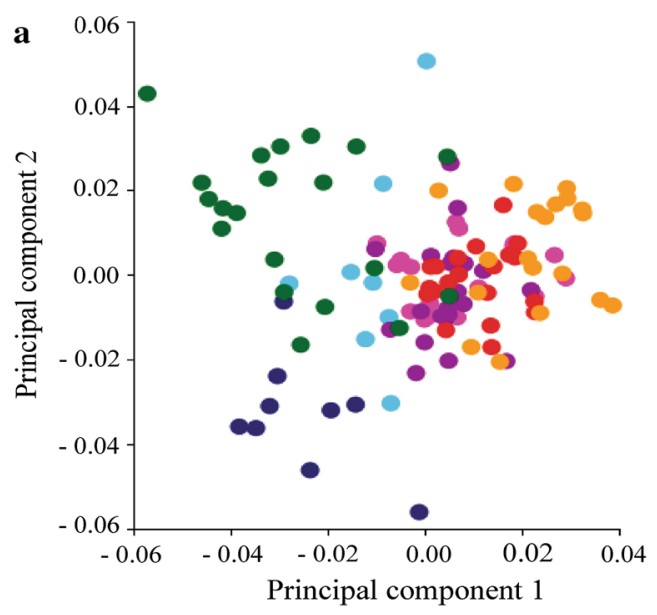

b

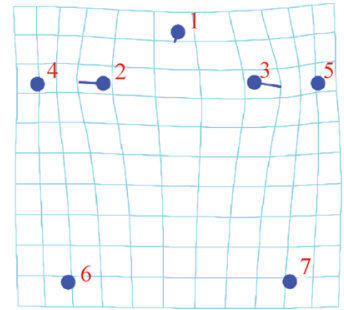

PC1

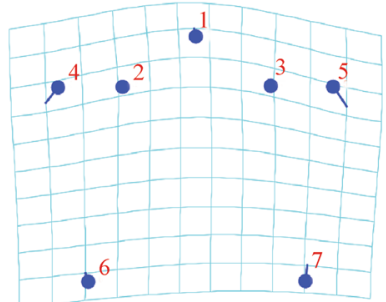

PC2

c

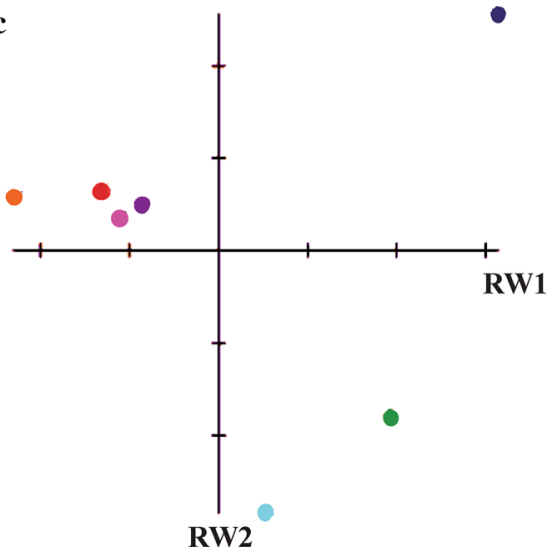

\section{Discussion}

Phenotypic variability may be related to partial or total genetic isolation among populations, as in the case of speciation (Skoracka et al. 2002). In this study, detailed morphological studies were performed using traditional morphometry and geometric methods to 
4Fig. 5 Morphometric geometric analysis for the prodorsal shield of Retracrus females from population associated with palm trees and heliconias in the Americas. a Principal component analysis (PCA). Individuals plotted against their values for the first two principal components. $\mathbf{b}$ Variations in shape $s$ are presented in the form of transformation grids along the principal components 1 and 2 axis. c Relative warps (RW) for values $\alpha=0$. Population consensus plotted against their values for the first two relative warps. Red circle: Cocos nucifera, Alagoas, Brazil; Orange circle: C. nucifera, Paraíba, Brazil; Violet circle: $C$. nucifera, Pernambuco, Brazil; Pink circle: C. nucifera, Rio Grande do Norte, Brazil; Light blue circle: Heliconia latispatha, San José, Costa Rica; Dark blue circle: H. pendula, Bahia, Brazil; Green circle: Syagrus romanzoffiana, São Paulo, Brazil. (Color figure online)

evaluate phenotypic differences among populations that have been preliminarly identified as $R$. johnstoni from different hosts. The occurrence of morphometric variability or similarity among populations can add clarity to the evaluation of their taxonomic status. The results of the different morphometric analyses were extensively consistent. The morphometric analyses, both traditional and geometric morphometrics, revealed significant differences among the populations that allowed for differentiating the populations studied. A morphometric pattern associated with the host plant was observed. Populations most morphometrically similar were those associated with a same host plant, coconut trees, collected from different Brazilian states-Alagoas, Paraíba, Pernambuco, and Rio Grande do Norte. The populations associated with the two heliconia species were morphometrically different from the palm tree populations and also from one another. Surprisingly, the population from $S$. romanzoffiana, also a palm tree species, is morphometrically distinct from the $C$. nucifera populations.

The morphometric differences observed support the hypothesis of the existence of a cryptic species-complex among the populations that have been identified as $R$. johnstoni associated with different host plants. The populations associated with $H$. latispatha from Costa Rica and $H$. pendula from Bahia, Brazil are identified as new to science; their taxonomic descriptions were prepared and presented below in this study. In addition to the morphometric variability found among the heliconia populations, our detailed morphological study revealed differences that may be used as diagnosis traits for the new taxa.

Besides morphometric studies granting higher confidence for redefining the taxonomic status of the Retracrus populations associated with heliconias, they also allowed note some morphometric traits that can be helpful to identifying these species. A set of significant morphometric differences, for which there was no overlap in the variation range, were highlighted in the remarks. Future taxonomic studies of Retracrus mites should also consider morphometric traits to enrich descriptions in this genus.

Morphometric traits can be particularly useful in Eriophyoidea taxonomy in the case of "cryptic species" or when identification of species in a genus is difficult due to its morphological simplicity (e.g., reduced prodorsal shield or genitalia ornamentation). For several groups of mites, morphometric traits are commonly used as taxonomic characters, as for example for Phytoseiidae (Chant and McMurtry 2007), Tetranychidae (Baker and Schwarz 1997), or Trombiculidae (Stekol'nikov 2008). Also for Eriophyoidea taxonomy morphometric traits have already been used to differentiate species (Ozman-Sullivan et al. 2006; Reis et al. 2014). Whenever possible definition of taxonomic morphometric traits for Eriophyoidea should result from morphometric studies evolving enough number of specimens and populations to ensure its reliability.

In comparing populations studied and the original description of $R$. johnstoni (Keifer 1965), the measurements of the body and setae lengths of the $C$. nucifera populations were closer to the holotype, except for the number of rays of the empodium higher in the $C$. 
nucifera individuals (Table 3). Unfortunately, it was not possible to access the $R$. johnstoni type material (see "Materials and methods"), but the information sent by Dr. Chetverikov allowed for some considerations about this character for which there was a discrepancy between the observations and the original description. According to Keifer (1965), $R$. johnstoni has an undivided empodium with six rays. In this study, only the Costa Rican $H$. latispatha population exhibited six rays in the empodium. All of the other populations analysed-from $C$. nucifera, S. romanzoffiana, and $H$. pendula-exhibited eight rays in the empodium. Although the $R$. johnstoni material obtained by Dr. Chetverikov was not well preserved, investigations revealed that there were eight rays in the empodium I of the female, not six as reported in the original description (Chetverikov, pers. comm.). The empodium of the mites of the genus Retracrus is very short, and under optical microscope observation counting the number of rays can be extremely difficult. It is possible that the microscopy resources available when the species $R$. johnstoni was described did not allow for accurately counting the number of rays of the empodium by Keifer (1965). It is thus suggested that the presence of eight rays in the empodium be considered as a taxonomic trait of $R$. johnstoni, not six as cited in the original description. Thus, the morphological traits of the studied $C$. nucifera populations align with those of $R$. johnstoni.

The $S$. romanzoffiana population of São Paulo State, Brazil, which has also been identified as $R$. johnstoni, was morphometrically different from the $C$. nucifera populations, which are closest to the type material presented by Keifer (1965). These results suggest that this population also comprises a cryptic species in the group $R$. johnstoni. It is possible that $R$. johnstoni populations identified from different palm trees do not consist of a single taxon but rather a species-complex. To clarify this hypothesis, given the unavailability of preserved $R$. johnstoni type material, obtaining topotype material of the species will be essential for comparing the populations from the diverse palms that have been reported as hosts. In addition to morphometric comparisons, as performed in this study, it will be important to conduct comparative studies using biological parameters and molecular data.

Among the performed analysis, the traditional CVA morphometric analyses allowed for better distinction among the populations studied (see Fig. 2). In addition to separation of the populations by host plant, supporting the identification of cryptic species in the genus, these analyses allowed for characterising the variability among populations of the same host, in the case of coconut tree populations from different states in Brazil; these populations entirely overlapped in the geometric morphometric analyses. Although the traditional CVA morphometric analyses has allowed the best discrimination among populations/species, we observed that results of the CVA applied to landmarks of the ventral region was very similar to that of the traditional CVA (Fig. 2a, b). This high similarity allowed us considering both analysis as presenting comparable efficiency for Retracrus species differentiation.

In this study despite the populations being better distinguished via traditional morphometric analyses than by geometric morphometric analyses, the use of landmark-based morphometric methods for mites of the genus Retracrus should be considered successful, as it allowed for separating populations/species and revealed interesting shape differences among them. Equally interesting results in studies of eriophyoid mites were obtained for species of the genus Aceria associated with Asteraceae of the genus Cirsium from Europe and the USA (Vidović et al. 2014) and for Aceria guerreronis Keifer populations from different continents (Navia et al. 2006). This is in contrast to what has been observed for other mite groups, such as Scutacariidae or Opiidae, for which geometric morphometry analyses have not proven useful in revealing interspecific differences but were useful for 
identification to the genus level (Baran et al. 2011; Jagersbacher-Baumann 2014). Thus, geometric morphometry methods should be considered useful for the eriophyoid mite systematics. The geometric morphometry analyses reveal and allow for recording differences which are often perceived by the taxonomist but difficult to express. Without the use of geometric morphometry methods, explanations for the different shapes of the taxa/ populations may not be appropriate due to its subjectivity. However, through the application of shape morphometric methods, these differences may be illustrated and recorded via deformation grids, subjected to multivariate analyses and graphically expressed, and, in addition, allow for future comparisons. In an integrative approach, these methods may be used together with other tools, including traditional morphometric analyses or molecular data.

Phytoptidae mites of the tribe Mackiellini belong to a Sierraphytoptini lineage of putatively archaic mites evolving on palm trees (Sukhareva 1994; Chetverikov and Sukhareva 2009). Until recently, all of the Mackiellini were thought to only associate with plants of family Arecaceae. The association of Mackiellini mites with Heliconiaceae is recent information and interesting from the perspective of the group's evolution. Chetverikov et al. (2014) suggested that the association of Retracrus with Heliconia plants may be a result of a host shift from arecacean to heliconiacean hosts, as the order Zingiberales (to which Heliconiaceae belongs) is phylogenetically quite remote from the order Arecales. Studies of the phylogenetic relationships among the species of Retracrus associated with heliconias described in this study and the species associated with palms could clarify this hypothesis. Given the new information, it would also be interesting to direct efforts for new collections of eriophyoids associated with numerous heliconia species-approximately 250 species are currently known (Mosca et al. 2004, de Castro et al. 2007), especially in their areas of natural occurrence in the Americas, as it is possible that many Retracrus species are associated with them.

The damage caused by new Retracrus species associated with H. latispatha in Costa Rica (Aguilar and Murillo 2012) has been quite severe. In addition to aesthetic damage to the foliage, it is possible that the species cause a run-out in the plants, compromising flower production. It will be extremely important to adopt quarantine measures to avoid the spread of Retracrus mites via international trade of materials for the vegetative propagation of heliconias, whether they be for commercial purposes (cut flowers, seedlings) or the exchange of genetic material (germplasm). It is possible that the distribution of the new species that has been observed causing damage to heliconias in Costa Rica is not restricted to this Central American country, and thus it will also be important to determine its current geographical distribution to suport adoption of appropriate quarantine measures.

\section{Taxonomic descriptions}

Retracrus costaricensis n. sp. Ferreira and Navia (Figs. 6, 7, 8) (Phytoptidae, Sierraphytoptinae, Mackiellini)

Diagnosis The new species $R$. costaricensis presents undivided empodium with six rays; one longitudinal line in the central basal area of the female genitalia; prodorsal shield with a sub-parallel line to the frontal lobe that continue as curved lines in the anterior shield; faint shield design, consisting in two irregular opposite curved lines (flat "U" lines) linked in the lateral area by curved longitudinal lines; dorsal ridge pronounced in the $3 / 4$ posterior opisthosoma (except telosomal rings). 

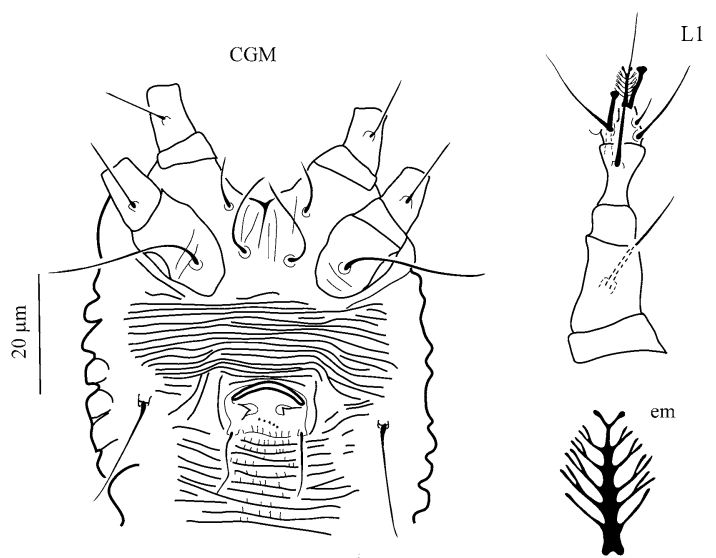

L2
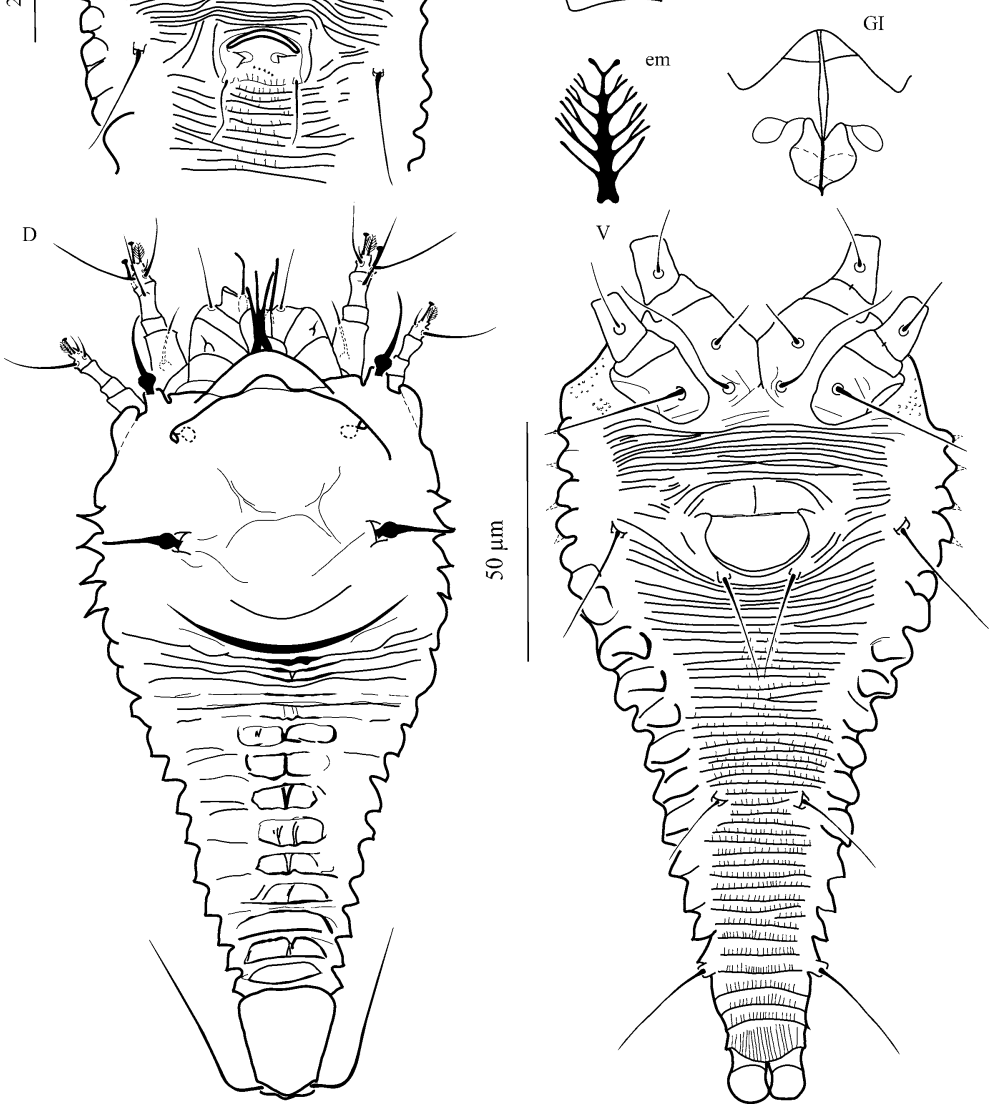

Fig. 6 Retracrus costaricensis n. sp. Ferreira and Navia, adult. $D$ dorsal habitus, female; $V$ ventral habitus, female; $C G M$ coxigenital region, male; $e m$ empodium enlarged, leg I, female; GI internal genitalia, female; L1 leg I, female; L2 leg II, female

Remarks The new species differs from all other Retracrus species by the undivided sixrayed empodium. (undivided empodium with eight rays in $R$. johnstoni (see "Discussion"), $R$. pupunha and $R$. heliconiae n. sp.; divided and apparently seven rays in $R$. elaeis). It is similar to $R$. johnstoni and to $R$. heliconiae $\mathrm{n}$. sp. in the presence of only one central longitudinal line in the basal area of the female genitalia; in $R$. elaeis and $R$. pupunha this area presents a transversal band of short longitudinal lines. $R$. costaricensis differs from all other species in the opisthosomal dorsal ridge that is attenuate in the first annuli and well 

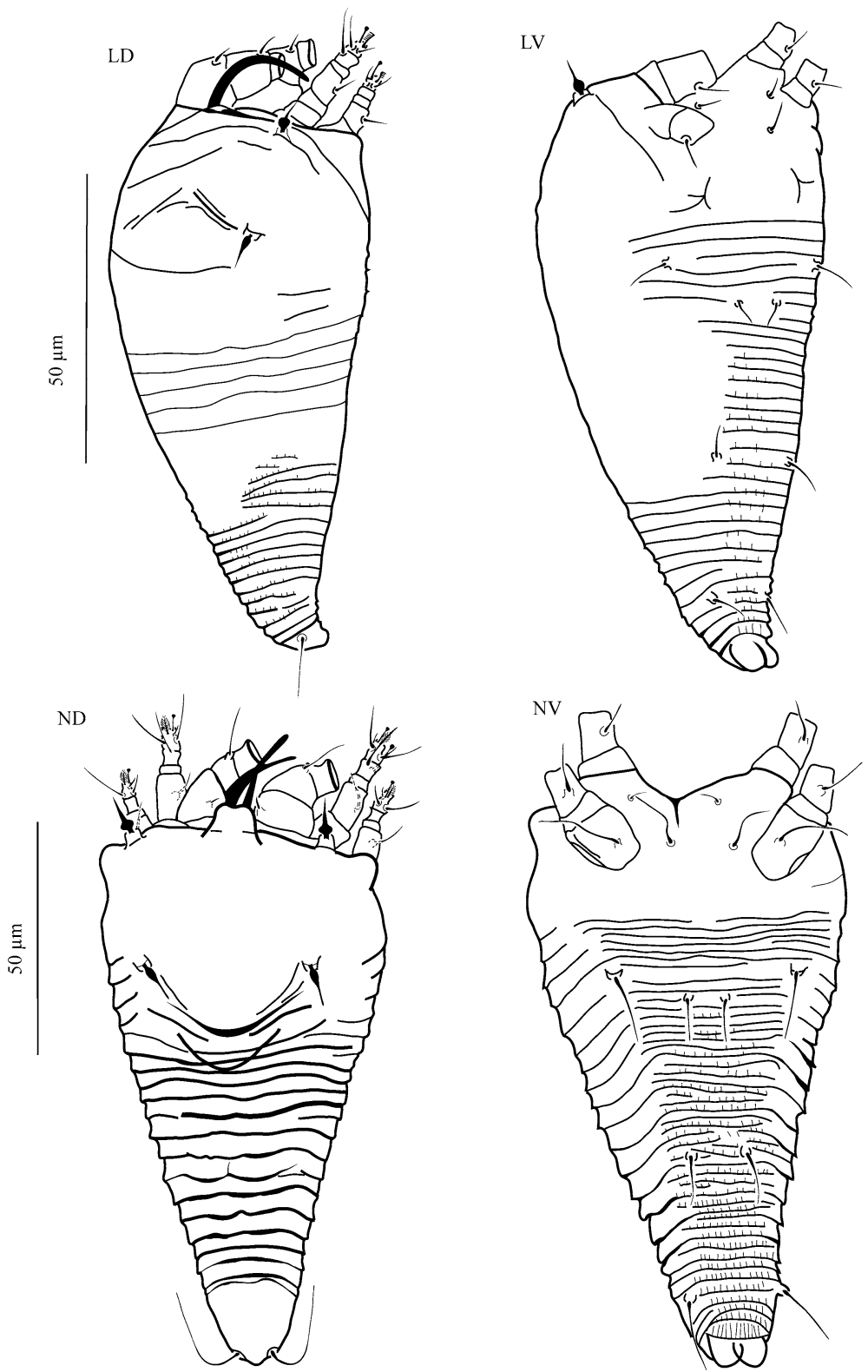

Fig. 7 Retracrus costaricensis n. sp. Ferreira and Navia, immatures. $L D$ dorsal habitus, larva; $L V$ ventral habitus, larva; $N D$ dorsal habitus, nymph; $N V$ ventral habitus, nymph

pronounced in the posterior opisthosoma (in $R$. elaeis (drawing) dorsal ridge is evenly pronounced in the whole opisthosoma; in $R$. johnstoni dorsal ridge is attenuate and more visible on anterior opisthosoma; in $R$. pupunha it extends on anterior opisthosoma, around eight first annuli; in $R$. heliconiae sp. $\mathrm{n}$. it is attenuate and more visible on posterior opisthosoma). The new species is similar $R$. johnstoni, $R$. elaeis and $R$. heliconiae $\mathrm{n}$. $\mathrm{sp}$. in 

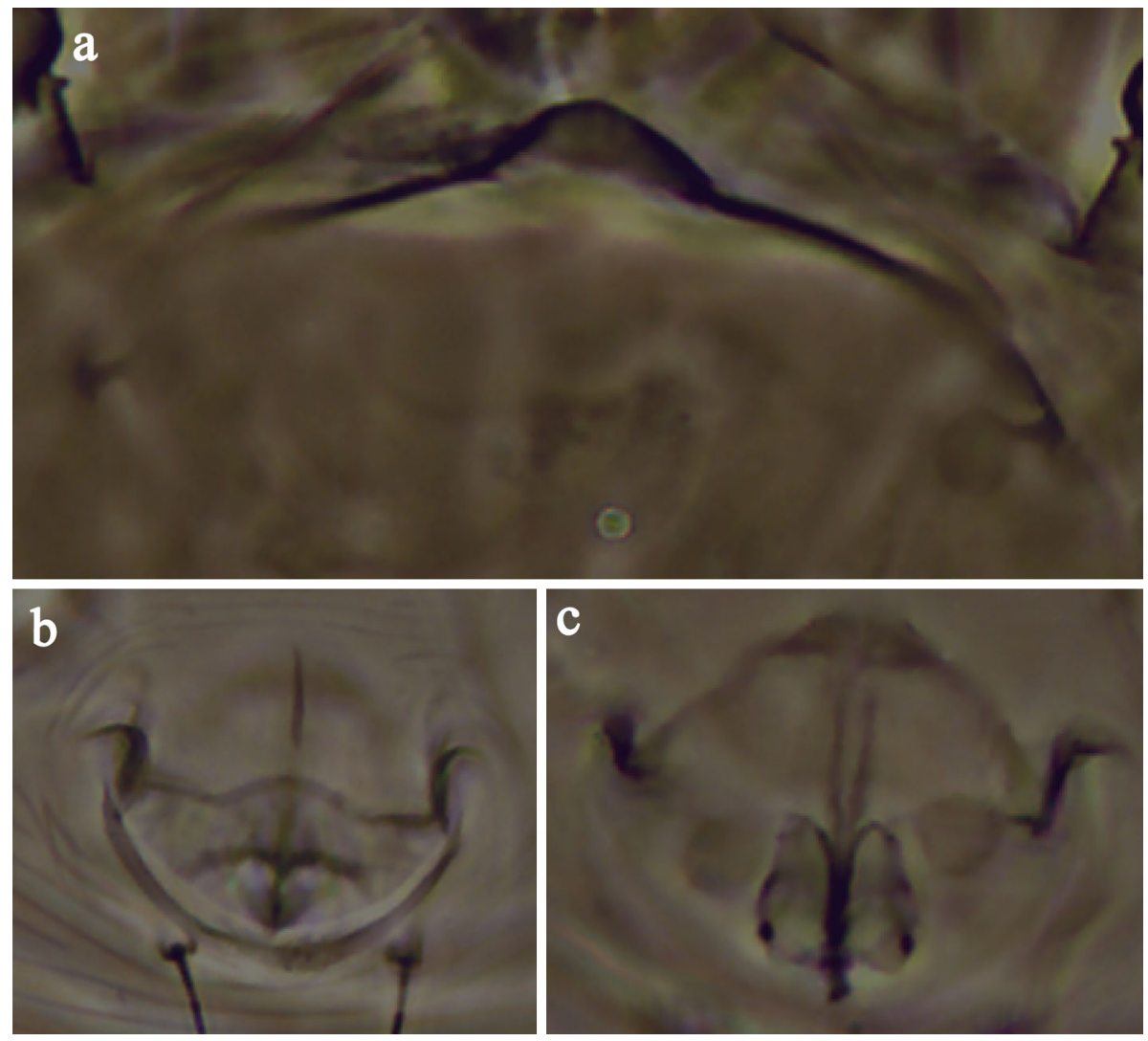

Fig. 8 Retracrus costaricensis n. sp. Ferreira and Navia, female phase contrast micrographs. a Anterior prodorsal shield, $\mathbf{b}$ external genitalia and $\mathbf{c}$ internal genitalia

the shape of prodorsal shield scapular ( $s c$ ) and external vertical setae (ve), with a bulbous base and tapering gradually; however it differs from $R$. pupunha in these traits since $s c$ and ve setae presents bulbous base followed by another dilatation.

The ratio between the body length and width provide information on the body shape and it can differentiate the new species from $R$. elaeis and $R$. pupunha. In $R$. costaricensis $\mathrm{n}$. sp. this ratio is around 2. It is lower than in $R$. elaeis (2.5-2.7) and in $R$. johnstoni type material (2.4), and higher than in $R$. pupunha (1.7).

Some morphometric traits allow differentiate $R$. costaricensis n. sp. from $R$. heliconiae n. sp.. The first species presents longer paraxial tibial seta $\left(l^{\prime}\right)$ and tibial solenidion $(\varphi)$ than $R$. heliconiae (in $R$. costaricensis $l^{\prime}$ lenght mean is 15.9 ranging from 13 to 19 while in $R$. heliconiae this mean is 10.5 ranging from 9 to 13 ; in $R$. costaricensis $\varphi$ lenght mean is 7.8 ranging from 8 to 10 while in $R$. heliconiae this mean is 7.1 ranging from 6 to 8 ).

Female $(n=10) \quad$ Body fusiform, 175 (161-178) and 87 (67-96) wide. Gnathosoma downcurved, 26 (22-33); pedipalp coxal seta (ep) 3 (3); dorsal pedipalp genual seta (d) 13 (12-14); cheliceral stylets 24 (23-30). Prodorsal shield subquadrangular, 68 (62-69) (measured from the top of frontal lobe to the first complete opisthosoma annuli), 82 (62-82) wide (measured from the lateral spine from prodorsal shield). Frontal lobe wide- 
based, rounded, 10 (9-12), 29 (24-30) wide. Scapular seta (sc) 16 (13-16), with bulbous base, inserted on prominent tubercles near the median-lateral margin of the shield, directed backwards, 33 (31-39) tubercles apart; external vertical seta (ve) 19 (17-20), with bulbous base on prominent tubercles inserted into the anterolateral margin of the prodorsal shield, directed forward, 41 (30-45) tubercles apart. Shield design consisting in a subparallel line to the frontal lobe and then extending on the $1 / 4$ anterior shield. In some specimens "balloons" like structures were observed on he anterior shield as rearing from this anterior concave line; these structures seems to be superficial but internal. Central shield design faint, consisting in two irregular opposite curved lines (flat "U" lines) linked in the lateral area by curved longitudinal lines. Posterior shield with a convex line restricted to the median area. Legs with all segments; all setae present except for paraxial tibial seta $\left(l^{\prime}\right)$ on leg II and antaxial genual seta $\left(l^{\prime \prime}\right)$ in legs I and II. Leg I 35 (28-37); femur 10 (10), basiventral femoral seta (bv) 13 (11-13); genu 3 (3); tibia 8 (7-9), $l^{\prime} 17$ (14-19), $\varphi 8$ $(8-10)$; tarsus 5 (5), antaxial fastigial tarsal seta $\left(f t^{\prime \prime}\right) 14(13-17)$, paraxial fastigial tarsal seta $\left(f t^{\prime}\right) 8(8-15)$, paraxial unguinal tarsal seta $\left(u^{\prime}\right) 4(4)$, tarsal solenidion $(\omega) 5(5)$, tarsal empodium 5 (5), simple, six-rayed. Legs II 31 (26-31); femur 10 (10), bv 14 (12-16); genu 3 (3); tibia 6 (6); tarsus 5 (5), ft" 12 (10-13), ft' 4 (4-5), $u^{\prime} 3$ (3), $\omega 5$ (5); tarsal empodium 4 (4-5), simple, six-rays. Coxigenital region with 10-11 annuli. Sternal line 12-13. Coxisternal plate: coxisternum I and II mostly smooth, few short lines between proximal seta on coxisternum I ( $1 a)$ and on coxa II; anterolateral seta on coxisternum I (1b) 6 (5-7), 16 (13-16) apart; proximal seta on coxisternum I (1a) 20 (12-24), 12 (10-14) apart; proximal seta on coxisternum II (2a) 18 (10-26), 33 (29-41) apart. Genitalia 17 (12-17), 27 (19-28) wide, one longitudinal line in the central basal area, coverflap smooth; genital seta $(3 a) 17$ (13-19). Spermathecal apparatus presenting a subtrapezoidal or subtriangular (in horizontal-projection) anterior genital apodeme; ovoid spermathecae directed laterad, thick sausage-like spermathecal tubes. Opisthosoma 14 (13-14) dorsal annuli, smooth, dorsal ridge pronounced in the $3 / 4$ posterior opisthosoma (except telosomal rings); 46 (45-46) ventral annuli, with thin elongated microtubercles visible from the ninth ventral ring until anal lobe. Lateral seta ( $c 2$ ) 21 (17-24), on ventral annulus 1 (1); ventral seta II (e) 15 (11-15), on annulus 27 (26-27), 14 (13-19) apart, 9 (9-10) microtubercles apart; ventral seta III (f) 19 (19-26), on annulus 42 (41-42), 24 (19-24) apart, 21 (20-21) microtubercles apart. Caudal seta (h2) 58 (46-58), accessory seta (hl) absent.

Male $(n=5) \quad$ Smaller than female, 140-157, 62-85 wide. Gnathosoma 20-25; ep 2-3; genual seta $d 7-11$; cheliceral stylets 15-26. Prodorsal shield as in female, 60-69, 56-74 wide. sc 12-17, 29-35 tubercles apart; ve 15-17, inserted under prominent tubercle on the margin of anterior prodorsal shield and 38-51 tubercles apart; frontal lobe 9-12, 20-26 wide. Legs as in females. Leg I 23-29; femur 9-10, bv 6-11; genu 3; tibia 6-7, $l^{\prime}$ 9-18, $\varphi$ 7-8; tarsus 4-5, ft' 10-15, ft' 7-11, $u^{\prime}$ 3-4, $\omega$ 5; tarsal empodium 4, simple, six-rayed. Leg II 24-28; femur 10-12, bv 11-14; genu 2-3; tibia 5; tarsus 4, ft' 9-14, ft' 3-4, $u^{\prime}$ 3-4, $\omega 4$, tarsal empodium 4, six-rayed. Coxigenital region with 14-16 annuli, smooth. Sternal line 13-14. Coxisternal plate: coxisternum I and II mostly smooth, faint longitudinal or diagonal lines, $1 b$ 2-5, 13-22 apart; $1 a$ 10-16, 8-11 apart; $2 a$ 10-18, 26-40 apart. Genitalia 6-8, 15-19 wide, eugenital seta as in the figure; seta 3a 12-15. Opisthosoma as in female, 14-15 dorsal annuli; 38-40 ventral annuli. c2 10-22, on anullus 1 ; $e$ 8-15, on annulus 20-22, 8-15 apart, 8-12 microtubercles apart; $f$ 14-20, on annulus 34-36, 20-24 apart, 22-28 microtubercles apart. $h 218-51$; $h 1$ absent. 
Nymph $(n=5) \quad$ Body fusiform, 108-139, 51-64 wide. Gnathosoma 21-25; ep 2; pedipalp seta $d$ 6-8; cheliceral stylets 18-26. Prodorsal shield subrectangular and smooth, 44-56, 51-64 wide. $s c$ in different position that in adults, near rear shield margin, 8-10, 28-34 tubercles apart; ve as in adults, 8-9, 32-44 tubercles apart. Frontal lobe 4-6, 21-23 wide, with different shape than in adults, narrower, subquadrangular, with subparalell sides, slightly emarginated in apical central area. Prominent projections lateral to ve seta tubercles. No shield design observed. Legs as in adults. Leg I 15-20; femur 6-8, bv 4-6; genu 2; tibia 2-4, $l^{\prime} 8-13, \varphi$ 5-6; tarsus 4, ft' 7-10, ft' 7-10, $\omega$ 4-5; tarsal empodium 3-4, simple, not possible to count rays. Leg II 15-18; femur 6-8, bv 5-7; genu 2; tibia 3; tarsus 4, $f t^{\prime \prime} 8-9, f t^{\prime} 2-4, \omega 4-5$; tarsal empodium 3-4, simple, no possible counting rays. Coxigenital region with 7-9 annuli anterior to seta $3 a$. Sternal line 13-14. Coxisternal plate: coxisternum I and II smooth, $1 b$ 2, 13-20 apart; $1 a$ 6-12, 8-13 apart; $2 a$ 9-12, 22-30 apart. Genitalia absent; 3a 6-7. Opisthosoma 15-16 dorsal annuli; 36-37 ventral annuli. As in adults dorso-ventral differentiation, with dorsal annuli less numerous than ventral ones. Dorsal ridge not pronounced as in adults; attenuate relief along the whole opisthosoma. $c 2$ 11-14; e 6-11, on annulus 19-20, 9-11 apart, 4-5 microtubercles apart; $f$ 10-14, on annulus 32-33, 11-12 microtubercles apart. h2 12-19; hl absent.

Larva $(n=2) \quad$ Body slightly fusiform, 109-110, 47-56 wide. Gnathosoma 18-22; ep 2; pedipalp seta $d 4-5$; cheliceral stylets 22-23 long. Prodorsal shield, subrectangular with lines between and above $s c, 31-41,47-56$ wide. $s c$ as in adults, 5-6, 26-30 tubercles apart; $v e$ as in adults, 7, 22-24 tubercles apart. Frontal lobe not distinguishable. Shield design not visible except for some diagonal and curved lines between sc setae. Legs as in adults, except for $\varphi$ solenidion absent. Leg I 13-15; femur 6, bv 4; genu 2; tibia 3, $l^{\prime} 7-8$; tarso 3, $f t^{\prime \prime}$ 6, ft' 4-6, $\omega$ 4; tarsal empodium 3, simple, no possible counting rays. Leg II 13; femur 6, $b v$ 4; genu 2; tibia 3; tarsus 3, $f t^{\prime \prime} 4, f t^{\prime} 3, \omega 3$; tarsal empodium 3, no possible counting rays. Coxigenital region with 5-6 annuli anterior to seta $3 a$. Sternal line 9-10. Coxisternal plate: coxisternum I and II smooth, $1 b$ 3, 6 apart; $1 a$ 4-5, 5 apart; $2 a$ 5-6, 7 apart. Genitalia absent; 3a 3-4. Opisthosoma differs from adults, dorsal annuli not completely formed, no dorso-ventral differentiation, with dorsal annuli continuous with ventral ones; not possible to count dorsal annuli, 24-25 ventral annuli. c2 6; $e$ 6-7, on annulus 12, 10-12 apart, four microtubercles apart; $f 8$, on annulus 22, 11-12 microtubercles apart. $h 210-15$; $h 1$ absent.

Type material Female holotype, 56 female, male, larva e nymph paratypes from Heliconia latispatha Bentham (Heliconiaceae), colected in Campus de la Universidad de Costa Rica, São José, Costa Rica $\left(9^{\circ} 44^{\prime} 58.92^{\prime \prime} \mathrm{N} ; 8^{\circ} 45^{\prime} 12.53^{\prime \prime} \mathrm{O}\right)$, May 17 of 2010, by Prof. Dr. Hugo Aguilar. Holotype and paratype (38 specimens, 19 females, 8 males, 2 larvae and 5 nymphs in four microscope slides) deposited in the mite collection of Embrapa Recursos Genéticos e Biotecnologia, Brasília, DF, Brazil. Paratypes (19 specimens, 9 females, 3 males, 6 nymphs and 1 larva in six microscope slides) also deposited in the collection of the Laboratório de Acarologia, Departamento de Agronomia, Universidade Federal Rural de Pernambuco, Recife, PE, Brazil.

Relation to host plant Vagrant on the upper leaf surface. Numerous colonies, causing general chlorosis and/or rusty-brownwish spots, which can extends along the whole leaf blade.

Etymology The specific name "costaricensis" is derived from Costa Rica, the name of the country where the mite was collected from. 


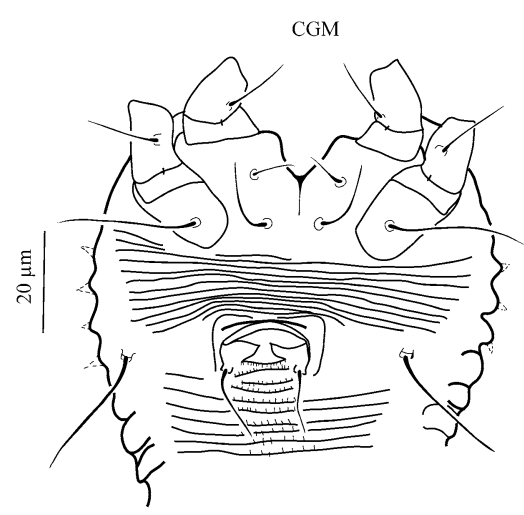

L1

$\mathrm{D}$
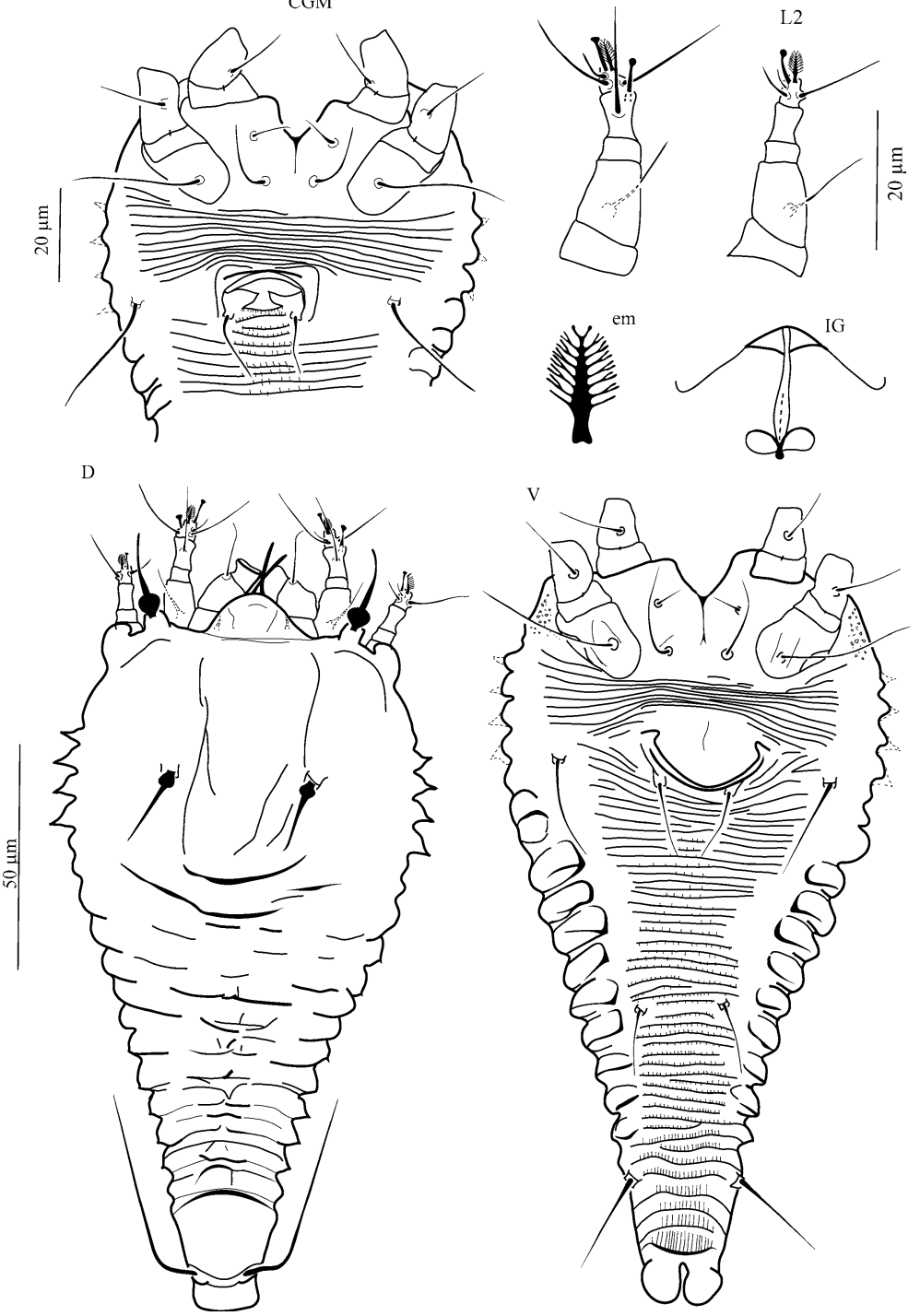

Fig. 9 Retracrus heliconiae n. sp. Ferreira and Navia, adult. $D$ dorsal habitus, female; $V$ ventral habitus, female; $C G M$ coxigenital region, male; em empodium enlarged, leg I, female; $G I$ internal genitalia, female; L1 leg I, female; L2 leg II, female

Retracrus heliconiae n. sp. Ferreira and Navia (Figs. 9, 10) (Phytoptidae, Sierraphytoptinae, Mackiellini)

Diagnosis The new species $R$. heliconiae presents undivided empodium with eight rays; one longitudinal line in the central basal area of the female genitalia coverflap; faint shield design consisting in irregular parallel longitudinal lines on the central area close and internal to scapular seta $(s c)$ tubercles, extending from frontal lobe base to near rear shield 

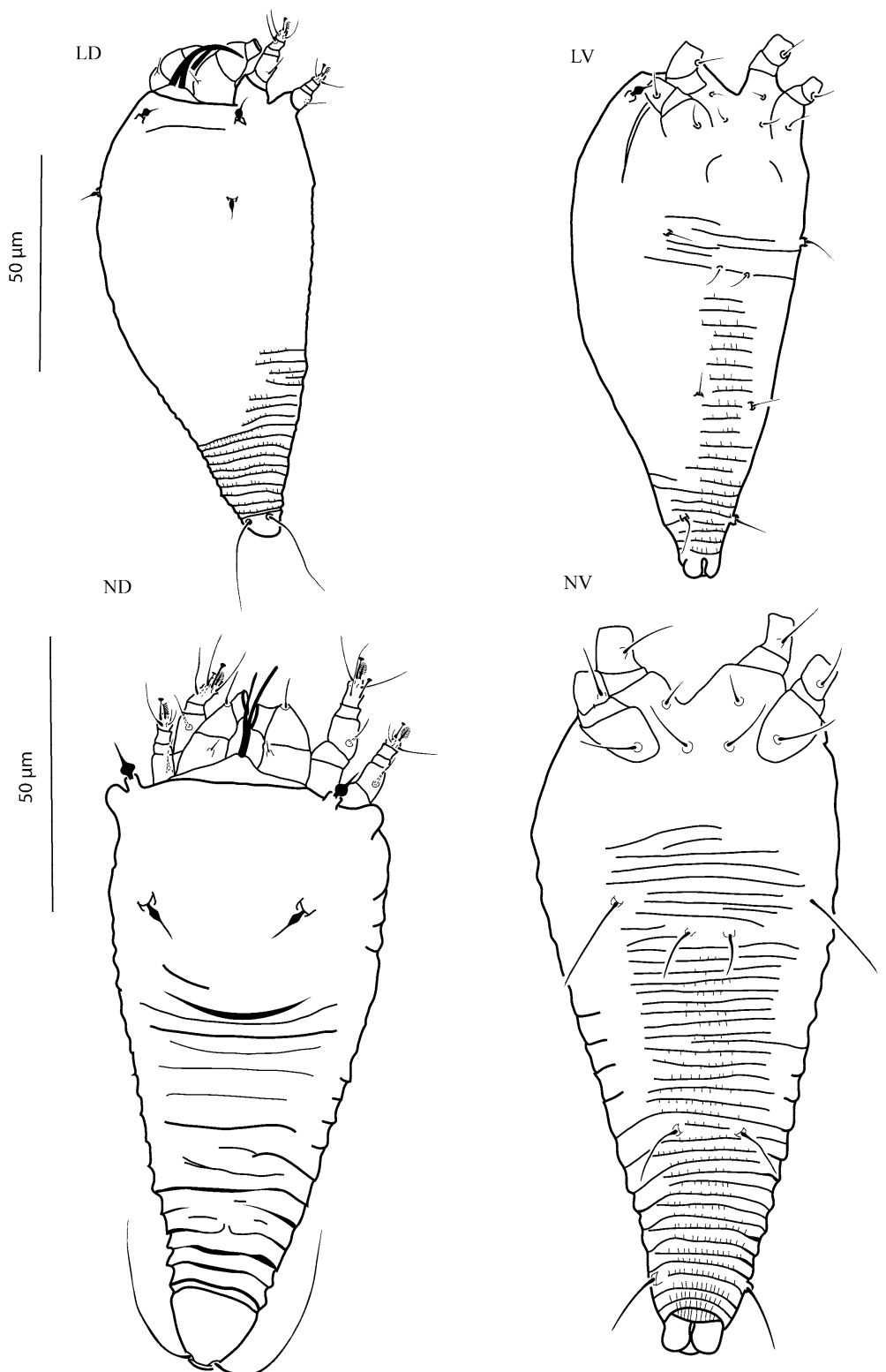

Fig. 10 Retracrus heliconiae n. sp. Ferreira and Navia, immatures. $L D$ dorsal habitus, larva; $L V$ ventral habitus, larva; $N D$ dorsal habitus, nymph; $N V$ ventral habitus, nymph

margin; faint or irregular delimitation of first dorsal annuli; and dorsal ridge attenuate, noticeable only in the $1 / 2$ posterior opisthosoma (except telosomal rings).

Remarks The new species is similar to R. johnstoni and $R$. pupunha in the undivided eight-rayed empodium (undivided empodium with six rays in $R$. costaricencis sp. n.; 
divided and apparently seven rays in $R$. elaeis). It is also similar to $R$. johnstoni and to $R$. costaricencis sp. $\mathrm{n}$. in the presence of only one central longitudinal line in the basal area of the female genitalia; in $R$. elaeis and $R$. pupunha this area presents a transversal band of short longitudinal lines. Retracrus heliconiae n. sp. resembles $R$. johsntoni in the dorsal ridge that is discernible only on the posterior opisthosoma differing from other species in this trait (in $R$. costaricencis it is attenuate on the anterior annuli and well pronounced on the posterior opisthosoma; in R. elaeis (drawing) it is evenly pronounced in the whole opisthosoma; in $R$. pupunha extends on anterior opisthosoma, around eight first annuli). The new species is similar $R$. johnstoni, $R$. elaeis and $R$. costaricencis $\mathrm{n}$. $\mathrm{sp}$. in the shape of prodorsal shield setae ( $s c$ and $v e$ ), with a bulbous base and tapering gradually (in $R$. pupunha sc and ve setae presents bulbous base followed by another dilatation).

The ratio between the body length and width in the new species (around 1.8) is closer $R$. pupunha (1.7) (in R. costaricensis n. sp. it is around 2; in R. elaeis vary from 2.5 to 2.7 ; in $R$. johnstoni type material is 2.4 ).

Some morphometric traits allow differentiate $R$. heliconiae n. sp. from $R$. costaricencis n. sp.; the first species presents shorter paraxial tibial seta $\left(l^{\prime}\right)$ and tibial solenidion $(\varphi)$ on leg I than $R$. costaricencis (in $R$. heliconiae $l^{\prime}$ lenght mean is 10.5 ranging from 9 to 13 while in $R$. costaricencis this mean is 15.9 , ranging from 13 to 19 ; in $R$. heliconiae $\varphi$ lenght mean is 7.1 ranging from 6 to 8 while in $R$. costaricencis this mean is 7.8 ranging from 8 to $10)$.

Female $(n=10)$ Body fusiform, 168 (150-168), 87 (70-97) wide. Gnathosoma downcurved, 26 (20-27); pedipalp coxal seta (ep) 3 (3); dorsal pedipalp genual seta (d) 11 (11-13); cheliceral stylets 22 (19-27). Prodorsal shield subquadrangular, 69 (62-70) (measured from the top of frontal lobe to the first complete opisthosoma annuli), 76 (76-93) wide (measured from the lateral spine from prodorsal shield), frontal lobe widebased, rounded, 11 (10-13), 24 (24-29) wide. Scapular seta (sc) 21 (16-21), with bulbous base, inserted on prominent tubercles near the median-lateral margin of the shield, directed backwards, 30 (27-34) tubercles apart; external vertical seta (ve) 21 (19-21), with bulbous base on prominent tubercles inserted into the anterolateral margin of the prodorsal shield and directed forward, 43 (40-43) tubercles apart. Faint shield design consisting in irregular parallel longitudinal lines on the central area close and internal to $s c$ tubercles, extending from frontal lobe base to near rear shield margin; irregular short lines in the frontal lobe area; faint or irregular delimitation of first dorsal annuli. Legs with all segments; all setae present except for $l^{\prime}$ on leg II and antaxial genual seta $\left(l^{\prime \prime}\right)$ in legs I and II. Leg I 29 (27-30); femur 10 (10), basiventral femoral seta (bv) 12 (10-12); genu 3 (3); tibia 9 (8-10), $l^{\prime} 12$ $(10-12)$, tibial solenidion $(\varphi) 8(6-8)$; tarsus $4(4)$, antaxial fastigial tarsal seta $\left(f t^{\prime \prime}\right) 18$ (15-18), paraxial fastigial tarsal seta $\left(f t^{\prime}\right) 12(10-12)$, tarsal solenidion $(\omega) 7$ (5-7), empodium 5 (4-5), simple, eight-rayed. Legs II 27 (24-29); femur 10 (10-11), bv 14 (11-14); genu 3 (3); tibia 6 (5-6); tarsus 4 (4), ft' 11 (9-11), ft' 5 (4-5), paraxial unguinal tarsal seta $\left(u^{\prime}\right) 3$ (3), $\omega 6$ (4-6); empodium 5 (4-5), simple, eight-rayed. Coxigenital region with 9-11 annuli. Sternal line 6-8. Coxisternal plate: coxisternum I and II smooth, anterolateral seta on coxisternum I (1b) 5 (5), 18 (15-19) apart; proximal seta on coxisternum I (1a) 19 (17-22), 11 (10-12) apart; proximal seta on coxisternum II (2a) 13 (10-15), 35 (29-42) apart. Genitalia 16 (13-17), 24 (22-27) wide, one longitudinal line in the central basal area, coverflap smooth; genital seta (3a) 16 (14-17). Spermathecal apparatus presenting a subtrapezoidal or subtriangular (in horizontal-projection) anterior genital apodeme; ovoid-rounded spermathecae directed postero-laterad, attached to longitudinal bridge (spermathecal tubes very short), half posterior longitudinal bridge 
thickened. Opisthosoma 12 (12-13) dorsal annuli, smooth; dorsal ridge attenuate, noticeable only in the $1 / 2$ posterior opisthosoma (except telosomal rings); 46 (44-46) ventral annuli, with thin, slightly elongated microtubercles visible from the seventh ventral ring until the anal lobe. Lateral seta (c2) 19 (14-19), on annulus 1 (1); ventral seta II (e) 11 (11-13), on annulus 27 (26-27), 16 (12-16) apart, 13 (13) microtubercles; ventral seta III (f) 18 (16-19), on annulus 46 (43-46), 21 (15-21) apart, 21 (21-26) microtubercles. Caudal seta (h2) 57 (35-67); acessory seta $(h l)$ absent.

Male $(n=5)$ Same size or somewhat longer than female, 150-178, 78-88 wide. Gnathosoma 20-25; ep 3; pedipalp seta $d$ 11-13; cheliceral stylets 19-27. Prodorsal shield as in female, 64-76, 70-81 wide. Frontal lobe as in female, 10-13, 25-30 wide. $s c$ as in female, 15-18, 28-38 tubercles apart; ve as in female 19-20, 38-47 tubercles apart. Legs as in females. Leg I 27-30; femur 11-12, bv 9-12; genu 3; tibia 8-10, $l^{\prime}$ 9-13, $\varphi$ 7-8; tarsus 4-5, ft" 9-16, ft' 5-9, $\omega$ 5-6; tarsal empodium 4-5, simple, eight-rayed. Leg II 26-28; femur 10-12, bv 12-14; genu 3; tibia 6-7; tarsus 4-5, $f^{\prime \prime}$ 7-13, $f t^{\prime} 4, \omega$ 4-5; tarsal empodium 4-5, simple, eight-rayed. Coxigenital region with 14-17 annuli. Sternal line 11-12. Coxisternal plate: coxisternum I and II smooth, 1b 5-6, 15-18 apart; 1a 15-20, 9-15 apart; $2 a$ 11-15, 32-38 apart. Genitalia 5-9, 13-19 wide, eugenital seta as in the figure; $3 a$ 11-14. Opisthosoma 14-15 dorsal annuli; 42-44 ventral annuli. c2 18-24, on anullus 1; $e$ 11-13, on annulus 23-24, 12-13 apart, 7-13 microtubercles apart; $f 14-22$, on annulus 38-39, 16-20 apart, 19-25 microtubercles apart. $h 2$ 49; $h 1$ absent.

Nymph $(n=2)$ Body fusiform 121-131, 56-61 wide. Gnathosoma 21-24; ep 2; pedipalp seta $d$ 7-8; cheliceral stylets 19-22. Prodorsal shield subquadrangular, smooth, 52-55, 56-61 wide. $s c$ as in adults, 8-9, 29-35 tubercles apart; ve as in adults, 8-9, 36-37 tubercles apart. Frontal lobe 4-5, 20-21 wide, with different shape than in adults, wider base, subtriangular, apically rounded. Prominent projections lateral to ve seta tubercles. No shield design observed. Legs as in adults. Leg I 19-20; femur 7, bv 6-7; genu 2; tibia 3, $l^{\prime}$ 10-14, $\varphi$ 5; tarsus 4, $f t^{\prime \prime}$ 9-11, $f t^{\prime}$ 9, $\omega$ 5; tarsal empodium 4, simple, no possible counting rays. Leg II 16-18; femur 6-8, bv 6-7; genu 2; tibia 3; tarsus 4, ft' 6-9, ft' 4, $\omega$ 4; tarsal empodium 4, not possible to count rays. Coxigenital region with 9-10 annuli anterior to seta $3 a$. Sternal line 14-15. Coxisternal plate: coxisternum I and II smooth, $1 b$ 3-4, 13 apart; 1 a 8, 9 apart; 2a 9-12, 26-27 apart. Genitalia absent; 3a 6-9. Opisthosoma 14 dorsal annuli; 34-37 ventral annuli. As in adults dorso-ventral differentiation, with dorsal annuli less numerous than ventral ones. Dorsal ridge very attenuate, noticeable only on the last dorsal annuli (except telosomal rings); anterior annuli almost flat. $c 213-18$; e 6-10, on annulus 18, 11 apart, 5-7 microtubercles apart; $f$ 13-15, on annulus 30-33, 16-17 apart, 12-13 microtubercles apart. $h 2$ 27-28; $h 1$ absent.

Larva $(n=2) \quad$ Body slightly fusiform, 114-115, 45-57 wide. Gnathosoma 23-26; ep 2; pedipalp seta $d 4$; cheliceral stylets 25 . Prodorsal shield not possible to distinguish porterior margin, 45-57 wide. sc 6, on small tubercles, 30-31 tubercles apart; ve 5-7, on small tubercles, on the anterior prodorsal shield, 23 tubercles apart. Frontal lobe 4, broad based, apically rounded. Shield design not visible except for a transversal line on anterior shield. Legs as in adults, except for the tibial solenidion $\varphi$ absent. Leg I 14-16; femur 5-6, bv 4-5; genu 2; tibia 3, $l^{\prime}$ 6-7; tarsus 3, $f t^{\prime \prime}$ 6-7, $f t^{\prime}$ 6-7, $\omega 4$; tarsal empodium 4, simple, not possible to count rays. Leg II 13-14; femur 5-6, bv 3-4; genu 2; tibia 3; tarsus 3, $f t^{\prime \prime} 7-6, f t^{\prime}$ 4, $\omega$ 4; tarsal empodium 4, not possible to count rays. Coxigenital region not possible to count annuli anterior to seta $3 a$. Coxisternal plate: coxisternum I and II smooth, $1 b 3-4$, 9-12 apart; 1a 6-8, 6-7 apart; 2a 6, 19-21 apart. Genitalia absent; 3a 4. Opisthosoma 
differs from adults, dorsal annuli not completely formed, no dorso-ventral differentiation observable, apparently dorsal annuli continuous with ventral ones; not possible to count dorsal annuli; 24 ventral annuli. $c 2$ 8; e 5-7, on annulus 11, 11 apart, 4-5 microtubercles apart; $f$ 8-10, on annulus 19-20, 10 apart, 4-5 microtubercles apart. $h 2$ 12-16; hl absent.

Type material Female holotype, 36 females, male, larvae and nymph paratypes from Heliconia pendula (Heliconiaceae), colected in campus of Universidade Estadual de Santa

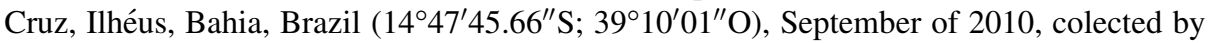
Anibal Ramadan Oliveira. Holotype and paratype (16 specimens, 11 females, 4 males and 1 larvae in 2 microscope slide) deposited in the collection of mites of Embrapa Recursos Genéticos e Biotecnologia, Brasília, DF, Brazil. Paratypes (21 specimens, 9 females, 4 males, 4 nymphs and 4 larvae in 2 microscope slides) deposited in the collection of the Laboratório de Acarologia, Departamento de Agronomia, Universidade Federal Rural de Pernambuco, Recife, Brazil, PE.

Relation to host plant Vagrant on the upper leaf surface without aparent injuries, found in low population density.

Etymology The species name "heliconiae" is derived from the genus of the host plant Heliconia.

Acknowledgments To National Council for Scientific and Technological Development (CNPq), Brazil and FACEPE, Pernambuco, Brazil, by the financial support. Authors DN and MGC Gondim Jr. are also grateful to CNPq for research fellowships. We sincerely thank Prof. Dr. Hugo Aguilar (Universidad de Costa Rica, São José, Costa Rica) and Prof. Dr. Anibal Ramadan Oliveira (Universidade Estadual de Santa Cruz, Ilhéus, Bahia, Brazil) for being the first to discover the new species described in this manuscript, collecting and sending samples for identification. We also would like to thank Prof. Dr. Philipp Chetverikov (SaintPetersburg State University, St. Petersburg, Russia) for examining and providing detailed information on Retracrus johnstoni specimens; Prof. Dr. José Wagner da Silva Melo (Federal University of Ceará, Ceará, Brazil), for statistical support and valuable suggestions for revision of the manuscript; and Dr. Norton Polo Benito (Embrapa Recursos Genéticos e Biotecnologia) for support in graphs edition.

\section{References}

Abreu RLS (2004) Durabilidade natural do estipe de pupunha (Bactris gasipaes Kunth, Arecaceae) II: insetos. Acta Amaz 34:459-465

Adams DC, Rohlf FJ, Slice DE (2004) Geometric morphometrics: ten years of progress following the 'revolution'. Ital J Zool 71:5-16. doi:10.1080/11250000409356545

Aguilar H, Murillo P (2012) Nuevos hospederos y registros de ácaros fitófagos para Costa Rica: período 2008-2012. Agron Costarric 36:11-28

Amrine JW Jr, Manson DCM (1996) Preparation, mounting and descriptive study of eriophyoid mites. In: Lindquist EE, Sabelis MW, Bruin J (eds) Eriophyoid mites: their biology, natural enemies and control. Elsevier, The Netherlands, pp 388-396

Amrine JW Jr, Stasny TAH (1994) Catalog of the Eriophyoidea (Acarina: Prostigmata) of the world. Indira Publishing House, West Bloomfield

Armstrong KF, Ball SL (2005) DNA barcodes for biosecurity: invasive species identification. Philos Trans R Soc Lond B Biol Sci 360:1813-1823. doi:10.1098/rstb.2005.1713

Arthur AL, Miller AD, Weeks AR (2011) Genetic markers indicate a new species complex of emerging pest mites in Australian grains. Ann Entomol Soc Am 104:402-415

Baker AS, Schwarz HH (1997) Morphological differences between sympatric populations of the Poecilochirus carabi complex (Acari: mesostigmata: Parasitidae) associated with burying beetles (Silphidae: Nicrophorus). Syst Parasitol 37:179-185 
Baran S, Altun A, Ayyildiz N, Kence A (2011) Morphometric analysis of oppiid mites (Acari, Oribatida) collected from Turkey. Exp Appl Acarol 54:411-420

Becerra JM, Valdecasas AG (2004) Landmark superimposition for taxonomic identification. Biol J Linn Soc 81:267-327

Bickford D, Lohman DJ, Sodhi NS, Ng PKL, Meier R, Winker K, Ingram KK, Das I (2007) Cryptic species as a window on diversity and conservation. Trends Ecol Evol 22:148-155

Bookstein FL (1991) Morphometrics tools for landmark data: geometry and biology. EUA, New York

Bookstein FL, Chernoff B, Elder RL, Humphries Jr JM, Smith GR, Strauss RE (1985) Morphometrics in evolutionary biology. Special publication 15. Academy of Natural Sciences Press, Philadelphia

Boykin LM, Armstrong KF, Kubatko L, Barro P (2012) Species delimitation and global biosecurity. Evol Bioinform 8:1-37

Carew M, Schiffer M, Umina P, Weeks A, Hoffmann A (2009) Molecular markers indicate that the wheat curl mite, Aceria tosichella Keifer, may represent a species complex in Australia. Bull Entomol Res 99:479-486

Castagnoli M, Lewandowski M, Labanowski GS, Simoni S, Soika GM (2010) An insight into some relevant aspects concerning eriophyoid mites inhabiting forests, ornamental trees and shrubs. Exp Appl Acarol 51:169-189

Chant DA, McMurtry JA (2007) Illustrated keys and diagnosis for the genera and subgenera of the Phytoseiidae of the world (Acari: Mesostigmata). Indira Publishing House, West Bloomfield

Chetverikov PE, Sukhareva SI (2009) A revision of the genus Sierraphytoptus Keifer 1939 (Eriophyoidea, Phytoptidae). Zootaxa 2309:30-42

Chetverikov PE, Craemer C, Vishnyakov AE, Sukhareva SI (2014) CLSM anatomy of internal genitalia of Mackiella reclinata $\mathrm{n}$. sp. and systematic remarks on eriophyoid mites from the tribe Mackiellini Keifer, 1946 (Eriophyoidea: Phytoptidae). Zootaxa 3860:261-279

Clarke FC, Pretorius E (2005) A comparison of geometric morphometric analyses and cross-breeding as methods to determine relatedness in three Amblyomma species (Acari: Ixodidae). Int $\mathrm{J}$ Acarol 31:393-405

de Castro CEI, May A, Gonçalves C (2007) Atualização da nomenclatura de espécies do gênero Heliconia (Heliconiaceae). Rev Bras Hort Ornam 13:38-62

de Lillo E, Craemer C, Amrine JW Jr, Nuzzaci G (2010) Recommended procedures and techniques for morphological studies of Eriophyoidea (Acari: Prostigmata). Exp Appl Acarol 51:283-307

Duso C, Castagnoli M, Simoni S, Angeli G (2010) The impact of eriophyoids on crops: recent issues on Aculus schlechtendali, Calepitrimerus vitis and Aculops lycopersici. Exp Appl Acarol 51:151-168

El-Halawany ME, Abdel-Samad MA, El-Naggar ME (2001) Mites inhabiting date palms. In: Proceedings of second international conference on date palms, U.A.E. Al-Ain, pp 366-373

Furiatti RS (2001) Principais pragas da pupunheira. In: Kultchetscki L, Chaimsohn FP, Gardingo JR (eds) Palmito pupunha (Bactris gasipaes Kunth.): a espécie, manejo agronômico, usos e processamentos. Ponta Grossa, UEPG, pp 91-93

Genty P (1980) Estudios entomológicos com relacción a la palma africana em América Latina. Palmas (Colombia) 5:22-31

Genty P, Reyes E (1977) Un nouvel acarien du palmier à huile: 1'Eriophyidae Retracrus elaeis Keifer. Oléagineux 32:255-262

Gondim Jr MGC (2000) Ácaros de palmeiras (Arecaceae) em áreas dos estados de São Paulo e Pernambuco. Thesis, Universidade de São Paulo, Piracicaba

Hebert PDN, Penton EH, Burns JM, Janzen DH, Hallwachs W (2004) Ten species in one: DNA barcoding reveals cryptic species in the neotropical skipper butterfly Astraptes fulgerator. Proc Natl Acad Sci USA 101:14812-14817

Jagersbacher-Baumann J (2014) Species differentiation of scutacarid mites (Heterostigmatina) using multivariate morphometric methods. Exp Appl Acarol 62:279-292

Keifer HH (1965) Eriophyid Studies B-16. Bureau of Entomology, California Department of Agriculture, $7-8$

Keifer HH (1975) Eriophyid Studies C-10. Bureau of Entomology, California Department of Agriculture 3-4

Klimov PB, Bochkov AV, OConnor BM (2006) Host specificity and multivariate diagnostics of cryptic species in predacious cheyletid mites of the genus Cheletophyes (Acari: Cheyletidae) associated with large carpenter bees. Biol J Linn Soc 87:45-58

Klingenberg CP (2011) MorphoJ: an integrated software package for geometric morphometrics. Mol Ecol Resour 11:353-357 
Lindquist EE, Amrine JW Jr (1996) Systematics, diagnoses for major taxa, and keys to families and genera with species on plants of economic importance. In: Lindquist EE, Sabelis MW, Bruin J (eds) Eriophyoid mites: their biology, natural enemies and control. Elsevier, The Netherlands, pp 33-87

Lindquist EE, Sabelis MW, Bruin J (1996) Eriophyoid mites: their biology, natural enemies and control. World Crop Pests, vol 6. Elsevier, The Netherlands

Marcus L F (1990) Traditional morphometrics. In: Rohlf FJ, Bookstein FL (eds) Proceedings of the Michigan morphometrics workshop. Spec. Publ. No. 2. University of Michigan Museum of Zoology, Ann Arbor, pp 77-122

Miller AD, Skoracka A, Navia D, Mendonça RS, Szydło W, Schultz MB, Smith CM, Truol G, Hoffmann AA (2013) Phylogenetic analyses reveal extensive cryptic speciation and host specialization in an economically important mite taxon. Mol Phylog Evol 66:928-940

Mosca LJ, Queiroz de MB, Almeida AS, Cavalcante RA, Alves RE (2004) Helicônia: Descrição, Colheita e Pós-Colheita (Documento 91). Fortaleza, Brazil

Navia D, Moraes GJ, Querino RB (2006) Geographic variation in the coconut mite, Aceria guerreronis Keifer (Acari: Eriophyidae): a geometric morphometric analysis. Int J Acarol 32:301-314

Navia D, Gondim MGC Jr, Moraes GJ (2007) Eriophyoid mites (Acari: Eriophyoidea) associated with palm trees. Zootaxa 1389:1-30

Navia D, de Moraes GJ, Querino RB (2009) Geographic pattern of morphological variation of the coconut mite, Aceria guerreronis Keifer (Acari: Eriophyidae), using multivariate morphometry. Braz J Biol 69(3):773-783

Navia D, Ochoa R, Welbourn C, Ferragut F (2010) Adventive eriophyoid mites: a global review of their impact, pathways, prevention and challenges. Exp Appl Acarol 51:225-255

Ochoa R, Aguilar H, Vargas C (1991) Ácaros fitófagos de America Central: guia ilustrada. Catie, Turrialba

Ochoa R, Aguilar H, Vargas C (1994) Phytophagous mites of Central America: an illustrated guide. Catie, Turrialba

Oldfield GN (1996) Diversity and host plant specificity. In: Lindquist EE, Sabelis MW, Bruin J (eds) Eriophyid mites: their biology, natural enemies and control. Elsevier, Amsterdam, pp 199-216

Ozman-Sullivan SK, Amrine JW Jr, Walter DE (2006) A new species of eriophyoid mite (Acari: Eriophyidae) on sugarcane in Australia. Int J Acarol 32:387-395

Pfingstl T, Schäffer S, Krisper G (2010) Re-evaluation of the synonymy of Latovertex Mahunka, 1987 and Exocepheus Woolley and Higgins, 1968 (Acari: Oribatida: Scutoverticidae). Int J Acarol 36:327-342

Pretorius E, Clarke FC (2000) Geometric morphometric analyses of the male and female body shape of Hyalomma truncatum and H. marginatum rufipes (Acari: Ixodidae). Int J Acarol 26:229-238

Rafter MA, Hereward JP, Walter GH (2013) Species limits, quarantine risk and the intrigue of a polyphagous invasive pest with highly restricted host relationships in its area of invasion. Evol Appl 6:1195-1207

Reis AC, Gondim MGG Jr, Navia D, Flechtmann CHW (2012) Eriophyoid mites (Acari: Prostigmata: Eriophyoidea) on palms (Arecaceae) from the Brazilian Amazon: a new genus and four new species. Zootaxa 3446:49-59

Reis AC, Gondim MGC Jr, Ferragut FJ, Navia D (2014) New eriophyoid mites (Prostigmata: Eriophyoidea) associated with palm trees (Arecaceae) from South America. Int J Acarol 40:230-246

Rohlf FJ (1997) Program TPSSMALL. Department of Ecology and Evolution, State University of New York, Stony Brook 1v

Rohlf FJ (1998) Program TPSRELW. Department of Ecology and Evolution, State University of New York, Stony Brook 1v

Rohlf FJ (1999) Shape statistics: procrustes superimpositions and tangent spaces. J Classif 16:197-223

Rohlf FJ (2010) TpsDig, ver. 2.16. Ecology and evolution. SUNY at Stony Brook. http://life.bio.sunysb.edu/ morph/

Rowell HJ, Chant DA, Hansell RIC (1978) The determination of setal homologies and setal patterns on the dorsal shield in the family Phytoseiidae (Acarina: Mesostigmata). Can Entomol 110:859-876

Santana DLQ, Flechtmann CHW (1998) Mite (Arthropoda: Acari) associates of palms (Arecaceae) in Brazil. I. Present status and new records. Rev Bras Zool 15:959-963

Santana DLQ, Flechtmann CHW, Lima MF (1994) Novos ácaros do coqueiro no Brasil. Aracaju, Brazil

SAS Institute (2002) SAS/STAT User's guide, verson 9.0, T.S level 2 MO. SAS Institute Inc, Cary, NC

Skoracka A (2009) Description of Abacarus lolii n. sp. (Prostigmata: Eriophyoidea: Eriophyidae), a cryptic species within a grass-feeding Abacarus complex. Intern J Acarol 35:405-417

Skoracka A, Dabert M (2010) The cereal rust mite Abacarus hystrix (Acari: Eriophyoidea) is a complex of species: evidence from mitochondrial and nuclear DNA sequences. Bull Entomol Res 100:263-272. doi:10.1017/S0007485309990216 
Skoracka A, Kuczynski L (2006) Is the cereal rust mite, Abacarus hystrix really a generalist? Testing colonization performance on novel hosts. Exp Appl Acarol 38:1-13

Skoracka A, Kuczynski L, Magowski W (2002) Morphological variation in different host populations of Abacarus hystrix (Acari: Prostigmata: Eriophyoidea). Exp Appl Acarol 26:187-193

Skoracka A, Smith L, Oldfield G, Cristofaro M, Amrine JW Jr (2010) Host-plant specificity and specialization in eriophyoid mites and their importance for the use of eriophyoid mites as biocontrol agents of weeds. Exp Appl Acarol 51:93-110

Skoracka A, Kuczynski L, Mendonça RS, Dabert M, Szydło W, Knihinicki D, Truol G, Navia D (2012) Cryptic species within the wheat curl mite Aceria tosichella (Keifer) (Acari: Eriophyoidea), revealed by mitochondrial, nuclear and morphometric data. Invertebr Syst 26:417-433

Skoracka A, Kuczyński L, Szydło W, Rector B (2013) The wheat curl mite Aceria tosichella (Acari: Eriophyoidea) is a complex of cryptic lineages with divergent host ranges: evidence from molecular and plant bioassay data. Biol J Linn Soc 109:165-180

Stekol'nikov AA (2008) Two new species of chigger mites (Acari: Trombiculidae) close to Neotrombicula minuta, application of nonlinear multivariate statistics. Acarina 16:21-29

Stekol'nikov AA, Klimov PB (2010) A revision of chiggers of the minuta species-group (Acari: Trombiculidae: Neotrombicula Hirst, 1925) using multivariate morphometrics. Syst Parasitol 77:55-69

Sukhareva SI (1994) Family Phytoptidae Murray 1877 (Acari: Tetrapodili), its consisting, structure and suggested ways of evolution. Acarina 2:47-72

Vidović B, Stanisavljevic L, Petanovic R (2010) Phenotypic variability in five Aceria spp. (Acari: Prostigmata: Eriophyoidea) inhabiting Cirsium species (Asteraceae) in Serbia. Exp Appl Acarol 52:169-181

Vidović B, Jojić V, Marić I, Marinkovic S, Hansen R, Petanovic R (2014) Geometric morphometric study of geographic and hostrelated variability in Aceria spp. (Acari: Eriophyoidea) inhabiting Cirsium spp. (Asteraceae). Exp Appl Acarol 64:321-335. doi:10.1007/s10493-014-9829-4

Wang CF, Kuo CC, Jeng ML, Huang KW (2011) Morphometric analyses reveal synonymy of two monotypic genera, Huangiella and Tumoris (Acari, Eriophyoidea, Eriophyidae). ZooKeys 102:1-11 